\title{
Nonmedicinal interventions in nonalcoholic fatty liver disease
}

\author{
Manuela G Neuman $\mathrm{PhD}^{1,2}$, Radu M Nanau BSc${ }^{1}$, Lawrence B Cohen MD MSc ${ }^{3}$
}

MG Neuman, RM Nanau, LB Cohen. Nonmedicinal interventions in nonalcoholic fatty liver disease. Can J Gastroenterol Hepatol 2015;29(5):241-252.

Unhealthy diet and lack of physical exercise are responsible for fat accumulation in the liver, which may lead to liver disease. Histologically, the severity of the disease has two stages: nonalcoholic fatty liver disease (NAFLD) and nonalcoholic steatohepatitis (NASH). NAFLD is defined by the presence of steatosis with no evidence of cellular injury such as hepatocyte ballooning. NASH is a distinct entity from NAFLD, and is characterized by the presence of inflammation with hepatocytes damage, with or without fibrosis. While several therapeutic strategies have been proposed to improve this condition, the present review aims to discuss nonmedicinal interventions used to reduce liver involvement or to prevent the disease altogether. The authors investigated dietary patterns and vitamin deficiencies associated with NAFLD, and their role in enhancing disease severity. Additionally, they reviewed the role of exercise and the use of interventions, such as as intragastric balloon and bariatric surgery, for improving disease progression. The authors propose monitoring disease progression or repair by following changes in cytoadipokine levels.

Key Words: Adipokine; Bariatric surgery; Cytokeratine 18; Intragastric balloon placement; Nonalcoholic fatty liver disease; Nonalcoholic steatohepatitis; Noninvasive biomarkers

\section{Les interventions non médicales en cas de stéatose hépatique non alcoolique}

Un régime malsain et le manque d'exercice physique sont responsables de l'accumulation de graisse dans le foie et peuvent favoriser une maladie hépatique. Sur le plan histologique, la gravité de la maladie se divise en deux phases : la stéatose hépatique non alcoolique (SHNA) et la stéatohépatite non alcoolique (SNA). La SHNA se définit par la présence de stéatose, sans manifestation de lésions cellulaires comme l'hypertrophie hépatocytaire. La SNA est une entité distincte de la SHNA et se caractérise par la présence d'inflammation et de lésions hépatocytaires, accompagnées ou non de fibrose. Il existe plusieurs stratégies thérapeutiques pour soigner cette maladie, mais la présente analyse porte sur les interventions non médicales utilisées pour réduire l'atteinte hépatique ou prévenir la maladie. Les auteurs ont exploré les profils diététiques et les carences en vitamines associées à la SHNA ainsi que leur rôle dans l'aggravation de la maladie. Ils ont également analysé le rôle de l'exercice et le recours à des interventions comme la chirurgie intragastrique à ballonnet et la chirurgie bariatrique pour en limiter la progression. Les auteurs proposent de surveiller la progression ou la réparation de la maladie après des modifications au taux de cytoadipokines.
$\mathrm{N}$ onalcoholic fatty liver disease (NAFLD) is a chronic liver condition characterized by insulin resistance, frequently associated with impaired glucose intolerance or type 2 diabetes mellitus, and hepatic fat accumulation ranging from simple steatosis to severe steatohepatitis (NASH) $(1,2)$. NAFLD is believed to be the most common cause of cryptogenic cirrhosis (1). The diagnosis of NAFLD is based on evidence of hepatic fatty infiltration, shown either by imaging or histology in the absence of other causes for secondary hepatic fat accumulation such as significant alcohol consumption, use of medication or presence of hereditary disorders known to produce hepatic lipidosis, or viral hepatitis B or C (1). NASH is mediated by other risk factors such as comorbid obesity and type 2 diabetes mellitus, in the presence or absence of the metabolic syndrome (1).

Morphological hallmarks of NAFLD-nonalcoholic steatohepatitis (NASH) include the severity of steatosis, hepatocyte ballooning, lobular inflammation, portal granulocytic inflammation, Mallory-Denk hyaline bodies and satellitosis $(2,3)$. The pathology subcommittee of the Clinical Research Network for NASH designed and validated a histological feature scoring system for the full spectrum of lesions of NAFLD. This group evaluated 14 histological features and, after analysis, proposed a NAFLD activity score. This activity score includes class 1, which is simple steatosis; class 2, steatosis with lobular inflammation; class 3, the additional presence of ballooned hepatocytes; and class 4, the presence of either Mallory-Denk hyaline bodies or fibrosis. These stages were correlated with increasing severity of disease and likelihood of progression to cirrhosis (2).
NASH is primarily a mitochondrial disease arising from the inability of the mitochondria to adapt to an oversupply of fat $(3,4)$. In addition to the mitochondrial dysfunction and oxidative stress in NASH, the translocation of gut-derived endotoxin to the portal vein initiates liver injury (3). These processes stimulate inflammatory responses. Lipotoxicity plays a key role in the pathogenesis of NAFLD. Dysregulation of hepatic metabolism - a result of lipotoxicity signalling and inflammatory processes - illustrates the cytokine imbalance that leads to liver injury (3).

Approximately $30 \%$ to $40 \%$ of patients with NAFLD develop $\mathrm{NASH}$. NASH is commonly associated with perisinusoidal and perivenular fibrosis that may progress to cirrhosis (5). Moreover, it is estimated that $10 \%$ to $30 \%$ of patients with NAFLD develop cirrhosis after 10 years (3). Additionally, NASH represents the second or third leading indication for liver transplant in North American and is projected to become the leading indication in the next 10 to 20 years (6). Based on data from United States adult liver transplantation databases, 2004 to 2013, Wong et al (6) concluded that the number of adults with NASH awaiting liver transplant has almost tripled.

Potential therapeutic interventions in NAFLD/NASH must involve a good understanding of the molecular mechanisms of the disease that may reduce hepatic steatosis and the development of necroinflammation/fibrosis by reversing defects at three levels including: reducing substrate supply for lipogenesis from excess dietary triglycerides or from excessive lipolysis and free fatty acid flux to the liver from insulin-resistant adipose tissue; activating key molecular steps that

${ }^{1}$ In Vitro Drug Safety and Biotechnology; ${ }^{2}$ Department of Pharmacology and Toxicology, Faculty of Medicine, University of Toronto; ${ }^{3}$ Division of Gastroenterology, Sunnybrook Health Sciences Centre, Department of Medicine, Faculty of Medicine, University of Toronto, Toronto, Ontario

Correspondence: Dr Manuela G Neuman, Department of Pharmacology and Toxicology and International Health, Faculty of Medicine, University of

Toronto, In Vitro Drug Safety and Biotechnology, Banting Institute, 100 College Street, Lab 217, Toronto, Ontario M5G 0A3.

Telephone 416-398-4880, e-mail manuela.neuman@utoronto.ca

Received for publication December 17, 2014. Accepted February 11, 2015 
TABLE 1

Mean serum 25-hydroxyvitamin D levels reported in selected studies

\begin{tabular}{|c|c|c|}
\hline Author (reference) & Study sample & Association with NAFLD \\
\hline Targher et al (15) & 60 patients with biopsy-proven NAFLD; 60 healthy controls & $51.0 \pm 22 \mathrm{nmol} / \mathrm{L}$ in NAFLD versus $74.5 \pm 15 \mathrm{nmol} / \mathrm{L}$ in control $(P<0.001)$ \\
\hline Pirgon et al (16) & $\begin{array}{l}87 \text { obese adolescents ( } 45 \text { NAFLD patients and } 43 \text { non-NAFLD } \\
\text { obese controls); } 30 \text { lean controls }\end{array}$ & $\begin{array}{l}29.5 \pm 18.4 \text { in obese NAFLD versus } 41.0 \pm 17.9 \text { in obese non-NAFLD versus } \\
48.1 \pm 22.2 \mathrm{ng} / \mathrm{mL} \text { in lean controls }\end{array}$ \\
\hline Dasarathy et al (17) & 148 NAFLD patients; 39 healthy controls & $21.2 \pm 10.4 \mathrm{ng} / \mathrm{mL}$ in NAFLD versus $35.7 \pm 6.0 \mathrm{ng} / \mathrm{mL}$ in control $(P=0.002)$ \\
\hline Hao et al (18) & $\begin{array}{l}514 \text { subjects with normal liver function tests and with } \\
\text { body mass index } \geq 18.5 \mathrm{~kg} / \mathrm{m}^{2} \text { to }<25 \mathrm{~kg} / \mathrm{m}^{2} \text { (76 NAFLD } \\
\text { patients and } 438 \text { non-NAFLD controls) }\end{array}$ & $\begin{array}{l}13.46 \pm 4.65 \mathrm{ng} / \mathrm{mL} \text { in NAFLD versus } 15.65 \pm 5.89 \mathrm{ng} / \mathrm{mL} \text { in non-NAFLD } \\
\text { controls }(P=0.002)\end{array}$ \\
\hline Küçükazman et al (19) & $\begin{array}{l}211 \text { subjects undergoing NAFLD examination (154 NAFLD } \\
\text { patients and } 57 \text { non-NAFLD controls) }\end{array}$ & $\begin{array}{l}12.3 \pm 8.9 \mathrm{ng} / \mathrm{dL} \text { in NAFLD versus } 20 \pm 13.6 \mathrm{ng} / \mathrm{dL} \text { in non-NAFLD controls } \\
(\mathrm{P}<0.001)\end{array}$ \\
\hline
\end{tabular}

NAFLD Nonalcoholic fatty liver disease

stimulate fatty acid oxidation and/or inhibit hepatic lipogenesis (ie, AMP-activated protein kinase); or by ameliorating the inflammation cascade generated by mitochondrial dysfunction from fat overload (ie, activation of Kupffer cells, local production of cytokines, induction of apoptosis, etc) $(7-12)$.

Dietary intervention, the current standard of care for NAFLD and $\mathrm{NASH}$, primarily reduces substrate supply (fat and carbohydrate overload) with modest and variable secondary improvements on hepatic molecular steps and local inflammation. The present review discusses the roles of nutrition and exercise as well as intragastic balloon placement on the evolution and progression of NAFLD/NASH, with an emphasis on changes in serum levels of adipokines (primarily adiponectin and leptin) as a result of these interventions.

\section{DIETARY PATTERNS IN NAFLD}

Several dietary components have often been found to be lacking in NAFLD patients. For example, insufficient intake of vitamin C, vitamin $\mathrm{K}$, folate and omega-3 fatty acids were risk factors for NAFLD, while their increased consumption was protective $(13,14)$. In particular, low serum 25 -hydroxyvitamin $\mathrm{D}\left(25[\mathrm{OH}] \mathrm{D}_{3}\right)$ levels were measured among NAFLD patients compared with controls in several studies. These are summarized in Table 1 (15-19).

Serum $25(\mathrm{OH}) \mathrm{D}_{3}$ levels may independently predict NAFLD $(18,20)$. The association between lower serum $25(\mathrm{OH}) \mathrm{D}_{3}$ levels and increased NAFLD incidence was maintained after controlling for age, sex, body mass index (BMI), creatinine, calcium, homeostasis model assessment-insulin resistance and the presence of the metabolic syndrome (15). Decreased serum $25(\mathrm{OH}) \mathrm{D}_{3}$ levels further predicted histological severity of hepatic steatosis, hepatocyte ballooning, necroinflammation and fibrosis $(15,17,18)$.

Vitamin D status was assessed as insufficient in $50.6 \%$ and as deficient in $17.3 \%$ in a sample of 156 adolescents with NAFLD. Inadequate serum $25(\mathrm{OH}) \mathrm{D}_{3}$ levels at 17 years of age was a risk factor for NAFLD after adjusting for sex, race, physical activity, BMI and insulin resistance (21). Vitamin D supplementation was associated with increased serum $25(\mathrm{OH}) \mathrm{D}_{3}$ levels, and this was accompanied by decreases in serum malondialdehyde and high-sensitive C-reactive protein (CRP) levels in a NAFLD sample (22). Inadequate intake of antioxidant vitamin $C$ was noted in NAFLD patients (mean $[ \pm$ SD] $84.3 \pm 43.1 \mathrm{mg} /$ day) when compared with non-NAFLD control individuals $(144.2 \pm 63.1 \mathrm{mg} /$ day $)(\mathrm{P}=0.0001)$. A deficient level of vitamin $E$ was also described $(5.4 \pm 1.9 \mathrm{mg} /$ day in NASH versus $8.7 \pm 2.9 \mathrm{mg} /$ day in control; $\mathrm{P}=0.0001)$ (23).

Food components whose increased consumption is associated with NAFLD include fruits, nuts and grilled meat $(14,23)$. In particular, a higher Western dietary pattern (high intakes of fast food, red meat, processed meats, full-fat dairy products, fried potatoes, refined cereals, cakes and biscuits, confectionery, soft drinks, sauces and dressings) at 14 years was associated with a greater risk for NAFLD, assessed by liver ultrasound, at 17 years (OR 1.59 [95\% CI 1.17to 2.14]; $\mathrm{P}<0.005$ ) in a large sample of adolescents followed since birth (NAFLD was present in $15.2 \%$ ). This was strongly linked to BMI at 14 years of age, such that this association was predominantly observed among obese adolescents. In contrast, a healthy dietary pattern (high in whole grains, fruit, vegetables, legumes, fish, fibre, folic acid and most micronutrients, and low in energy derived from total fat, saturated fat and refined sugar) at 14 years of age was protective against NAFLD development by 17 years of age (OR 0.63 [95\% CI 0.41 to 0.96]; $\mathrm{P}=0.033$ ) (24). In contrast, a recent cross-sectional study found similar consumption of Western diet high in fat and sodium intake and low in intakes of suboptimal micronutrients between 74 patients with biopsy-proven NAFLD and 27 healthy controls (25).

Higher BMI and waist circumference predicted a higher incidence of NAFLD (42.6\%) in a sample of 82 obese children. Total carbohydrate intake was higher in NAFLD patients $(\mathrm{P}<0.001)$, while the intake of saturated fats was proportional to the degree of steatosis (13). Fried food consumption was associated with hepatic steatosis in a cross-sectional study of 74 overweight adolescents $(\mathrm{P}=0.04)$. Total fat intake $(\mathrm{P}=0.03)$ and the percentage of daily energy intake derived from fat $(\mathrm{P}=0.02)$ were associated with hepatic steatosis in this sample. Daily consumption of fibre was associated with lower visceral obesity $(\mathrm{P}=0.03)$ but had no influence on hepatic steatosis (26).

Overnutrition increases adipose tissue and results in insulin resistance, which favours high rates of free nonesterified fatty acid flux to the liver. This adds to the liver content of triacylglycerol, while triacylglycerol metabolites lead to a lipotoxic environment (27).

\section{PHYSICAL ACTIVITY}

Significantly lower proportions of NAFLD patients met recommendations for physical activity compared with healthy controls $(\mathrm{P}=0.02)$. Levels of physical activity were similar between NASH patients and subjects with simple steatosis. However, levels of physical activity were even lower among individual who also suffer from diabetes mellitus $(25,28)$. On the other hand, regular physical exercise decreased the risks of having elevated aspartate aminotransferase (AST) levels and of developing NAFLD in a large sample of apparently healthy, nondiabetic adults (29). Table 2 describes some of the results of various interventions using physical exercise in NAFLD patients (29-43).

A recent study suggests that short-term aerobic training (AT) can help reduce the risk for NAFLD progression by targeting hepatic lipid composition; this effect appears to be mediated by adiponectin (38). Physical activity was also shown to have beneficial effects on intrahepatic triglyceride content, but not on the hepatic lipoprotein kinetics (35). Both AT and resistance training led to decreases in intrahepatic lipid levels, independent of weight loss $(30,38,44,45)$. The combination of AT and resistance training generally led to better results than either intervention alone (32). Physical exercise was also associated with lower intrahepatic lipid levels independent of weight loss in a meta-analysis (46).

A multidisciplinary program of dietary and exercise advice for developing individualized goals was found to have a positive effect on stabilizing BMI, and in improving total and low-density lipoprotein cholesterol as well as improving serum alanine aminotransferase (ALT) and AST levels for up to one-year follow-up in a prospectively 
TABLE 2

Physical activity

\begin{tabular}{lll}
\hline Study; sample population & Physical activity regimen & Outcome \\
\hline Bae et al (29); & Physical exercise (30 min/day, & Physical exercise: lower odds of having elevated AST level (OR 0.85 [95\% Cl 0.74-0.99]) \\
$\begin{array}{c}\text { 72,359 healthy Korean } \\
\text { adults without diabetes }\end{array}$ & $\begin{array}{l}3 \text { times/week) for 3 months } \\
(\mathrm{n}=12,967)\end{array}$ & $\begin{array}{l}\text { and ALT (OR 0.74 [95\% Cl 0.67-0.81]) } \\
\end{array}$
\end{tabular}

Hallsworth et al (30);

19 sedentary adults with clinically defined NAFLD

Bhat et al (31);

42 NAFLD patients

de Piano et al (32);

58 obese adolescents

(28 with NAFLD)

No exercise $(n=59,392)$

RT for 8 weeks $(n=11)$

Continued normal treatment $(n=8)$

Regular AT (30 min/day for at least 5 days/week)

Interdisciplinary weight-loss therapy for 1 year

AT alone $(n=29)$

$A T+R T(n=29)$

Fealy et al (33);

13 obese NAFLD patients

Grønbæk et al (34);

117 obese NAFLD children

Sullivan et al (35);

18 obese NAFLD patients

Al-Jiffri et al (36);

100 type 2 diabetes male patients with NAFLD

Bacchi et al (37);

31 sedentary adults with

NAFLD and type 2 diabetes

Haus et al (38);

17 obese NAFLD patients

Khaoshbaten et al (39); 90 NAFLD patients

Malin et al (40); 13 obese NAFLD patients

Oh et al (41);

212 obese, middle-age men (19.8\% had abnormal liver function and suspicious liver fibrosis)

Oh et al (42);

169 obese NAFLD patients

Zelber-Sagi et al (43); 64 NAFLD patients without secondary liver disease
Treadmill walking for $60 \mathrm{~min} /$ day on 7 consecutive days

Moderate exercise (1 h/day) with restricted energy intake for 10 weeks

Exercise training (0-60 min for 5 days/week) for 16 weeks $(n=12)$ No intervention $(n=6)$

Physical training (3 times/week for 12 weeks) combined with dietary measures

Dietary measures only

Physical exercise for 4 months

AT $(n=14)$ day, 3 times/week for 3 months) $(n=45)$

Medical treatment alone $(n=45)$

AT for 7 days (60 min/day at $85 \%$ maximum heart rate)

Exercise training program without any dietary restriction for 12 weeks $(n=108)$

Dietary restriction program $(n=104)$

MVPA weight reduction for 12 weeks $<150 \mathrm{~min} /$ week $(\mathrm{n}=40)$

150-250 $\mathrm{min} /$ week $(\mathrm{n}=42)$

$\geq 250 \mathrm{~min} /$ week $(\mathrm{n}=87$ )

Home stretching $(n=31)$
RT $(n=17)$

RT: significant reduction in liver lipids $(P<0.05)$, improvements in lipid oxidation, glucose control and HOMA-IR

AT: decreased insulin resistance, BMI, waist circumference and ALT levels $(P<0.01$ for all), and improved NASH scores

AT: reduced body mass, BMI and fat mass in non-NAFLD patients

AT: reduced body mass, BMI, fat mass and visceral fat in NAFLD patients

AT + RT: improvement in body mass, BMI, fat mass, glycemia, total cholesterol and low-density lipoprotein-cholesterol in non-NAFLD patients

AT + RT: improvement in body mass, BMI, fat mass, glycemia, total cholesterol and low-density lipoprotein-cholesterol, and subcutaneous fat in NAFLD patients

AT + RT: higher magnitude of changes in total cholesterol, low-density lipoprotein-cholesterol,

ALT and adiponectin compared to AT alone in NAFLD

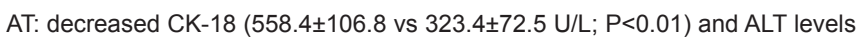

(30.2 \pm 5.1 vs $24.3 \pm 4.8 \mathrm{U} / \mathrm{L} ; \mathrm{P}<0.05)$

AT: increased whole body fat oxidation $(49.3 \pm 6.1 \mathrm{mg} / \mathrm{min}$ vs $69.4 \pm 7.1 \mathrm{mg} / \mathrm{min} ; \mathrm{P}<0.05)$ and circulating sFasL levels $(66.5 \pm 6.0 \mathrm{pg} / \mathrm{mL}$ vs $63.0 \pm 5.7 \mathrm{pg} / \mathrm{mL} ; \mathrm{P}<0.06)$

Training: weight loss and improvement in ultrasonographic liver steatosis, liver fat content and insulin resistance

Exercise training: decreased intrahepatic triglyceride content $(10.3 \pm 4.6 \%$; $P<0.05)$, with no influence on body weight, percent body fat, and very low density lipoprotein triglyceride and apolipoprotein B-100 secretion rates

Physical training + dietary measures: decreases in ALP $(P=0.0015)$, ALT $(P=0.0013)$,

AST $(p=0.0027)$, y-GTP $(p=0.0056)$, HOMA-IR $(P=0.0083)$ and BMI $(P=0.0094)$

Dietary measures only: no changes

Both AT and RT equally effectively reduced hepatic fat content $(P<0.001$ vs baseline), led to disappearance of hepatic steatosis (defined as hepatic fat content $>5.56 \%$ ) in almost a quarter of patients, increased insulin sensitivity during euglycemic clamp, and decreased total body fat mass, visceral adipose tissue, superficial subcutaneous abdominal adipose tissue and hemoglobin $\mathrm{A} 1 \mathrm{c}$

Short-term AT program (60 min/day of AT increased the liver polyunsaturated lipid index $(P<0.05)$, insulin sensitivity $(P<0.05)$, high treadmill walking at $85 \%$ of maximal molecular weight adiponectin levels $(P<0.05)$ and maximal oxygen consumption $(P<0.05)$ heart rate) for 7 consecutive days AT reduced reactive oxygen species production during oral glucose tolerance test

Medical treatment after AT (30 min/ Medical treatment + AT: decreased AST ( $41.5 \pm 2.7$ at baseline vs $29 \pm 9.5 \mathrm{IU} / \mathrm{L}$ at $3 \mathrm{months}$;

$\mathrm{P}=0.006)$ and $\mathrm{ALT}(61.1 \pm 3.6$ at baseline vs $44.9 \pm 2.4 \mathrm{IU} / \mathrm{L}$ at 3 months; $\mathrm{P}=0.01)$

AT: reduced insulin resistance $(P<0.05)$ and circulating fetuin-A levels $(P<0.02)$

Both regimens reduced body weight, waist circumference and visceral adipose tissue area, serum ALT and Y-GTP levels, and insulin resistance; dietary restriction program superior Exercise training increased adiponectin levels

Exercise training reduced serum levels of inflammation and oxidative stress markers such as ferritin and thiobarbituric acid reactive substances in subjects with suspected liver fibrosis

The degree of hepatic steatosis decreased more significantly in the $\geq 250 \mathrm{~min} /$ week group compared to the $<250 \mathrm{~min} /$ week groups

$\geq 250 \mathrm{~min} /$ wk MVPA associated with more pronounced decreases in abdominal visceral adipose tissue, levels of ferritin and lipid peroxidation, along with a significant increase in adiponectin levels than $<250 \mathrm{~min} /$ week MVPA

RT 3 times/week for 3 months $(n=33)$ RT reduced hepatorenal-ultrasound index $(P=0.017)$, total, trunk and android fat,

serum ferritin and total cholesterol levels

RT increased lean body mass

No difference in AST, ALT and Y-GTP levels

ALP Alkaline phosphatase; ALT Alanine aminotransferase; AST Aspartate aminotransferase; AT Aerobic training; BMI Body mass index; CK-18 Cytokeratin-18; Y-GTP Gamma-glutamyl transpeptidase; HOMA-IR Homeostasis model assessment-insulin resistance; MVPA Moderate to vigorous intensity physical activity; NAFLD Nonalcoholic fatty liver disease; NASH Nonalcoholic steatohepatitis; RT Resistance training; sFas Soluble Fas; vs versus 
tracked pediatric NAFLD population (47). Another multidisciplinary intervention consisting of personalized diet, physical exercise and behaviour therapy for three months led to a mean weight loss of $8 \%$, improvement in liver function tests and a decrease in the liver fat content in 12 NAFLD patients included in an open-label nonrandomized study (48). Weight loss $>10 \%$ was an additional predictor of disease remission in a sample of NAFLD patients undergoing an intervention program designed to increase energy expenditure and reduce caloric intake using lifestyle behavioural changes (49).

A recent study assessed the degree of weight loss necessary to improve the markers of hepatic function and insulin resistance in 100 type 2 diabetes male patients with NAFLD. Physical training combined with dietary measures led to improvements in liver function tests and insulin resistance, while no such changes were observed in the control group receiving dietary measures alone (36). The addition of AT to medical treatment led to an improvement in serum ALT and AST levels, along with an improvement in liver echogenicity compared with medical treatment alone (39).

The severity of NASH is inversely associated with the ability to oxidize fat (50). Exercise and diet modification were shown to reduce the degree of steatosis in nonobese NAFLD patients (51). NAFLD severity was correlated with intramuscular adipose tissue content in a cross-sectional study $(\mathrm{P}<0.01)$, suggesting that skeletal muscle fat accumulation may influence the pathogenesis and severity of NASH (52). Changes in intramuscular adipose tissue content were correlated with changes in weight $(\mathrm{P}<0.05)$, BMI $(\mathrm{P}<0.05)$, subcutaneous fat area $(P<0.01)$, triglycerides $(P<0.05)$, fasting plasma glucose $(P<0.01)$, insulin $(\mathrm{P}<0.05)$, homeostasis model assessment-insulin resistance $(\mathrm{P}<0.05)$, the quantitative insulin sensitivity check index $(\mathrm{P}<0.01)$, and histopathological assessments such as changes in steatosis and lobular inflammation ( $\mathrm{P}<0.01$ for both) (52). Improved hepatic steatosis with reduced insulin resistance, ALT levels and serum interleukin 6 (IL-6) levels were associated with voluntarily or electrically contracted quadriceps and hamstrings, independent of changes in muscle mass (53). A short-term AT program decreased serum markers of hepatic apoptosis in a small sample of obese NAFLD patients. Fealy et al (33) proposed that changes in the proapoptotic environment following short-term exercise are mediated by improved insulin sensitivity and increased oxidative capacity.

Fetuin-A is a liver protein believed to be associated with NAFLD and type 2 diabetes. Seven days of AT reduced insulin resistance $(\mathrm{P}<0.05)$ and circulating fetuin-A levels $(\mathrm{P}<0.02)$ in obese adults with clinically diagnosed NAFLD, with a correlation between these two parameters $(\mathrm{P}<0.04)$. These occurred independent of changes in body weight. This study suggests that improvements in glucose tolerance in patients with NAFLD after physical exercise may be mediated by lowering fetuin-A levels, particularly in skeletal muscles (40).

\section{ADIPOKINES AS BIOMARKERS OF NASH AND OBESITY IN ADOLESCENTS}

Noninvasive routine laboratory tests in NAFLD patients have been described in recent reviews $(54,55)$ and a large study $(56)$. In the present work, we focus on serum adipokines levels. Adipokines, such as adiponenctin, leptin and ghrelin, were measured in samples of obese children and adolescents, with or without NAFLD. These findings are presented in Table 3 (32,57-61).

The main adipokines studied in NAFLD are adiponectin, leptin and ghrelin. Differences in adiponectin levels between controls and NAFLD patients are generally small. Among NAFLD patients, adiponectin levels are generally decreased in NASH compared with simple steatosis, such that decreased adiponectin levels can be used to predict NAFLD progression (62). On the other hand, leptin levels are higher in NAFLD patients compared with controls (57). Blood leptin levels reflect total body fat, and correlate with fibrosis and insulin resistance (63).

Adiponectin, resistin and retinol-binding protein-4 could be used to differentiate between steatosis with elevated serum ALT levels and nonsteatotic obese patients. Adiponectin and resistin were significantly lower and retinol-binding protein-4 was significantly higher in obese children with advanced steatosis compared with obese children without liver steatosis. Leptin was not a good predictor of liver steatosis or hepatopathic obesity (57).

Adiponectin levels were negatively correlated with the NAFLD activity score in a recent meta-analysis (64). In this study, low adiponectin levels were associated with NAFLD progression to NASH, with nonsignificant differences in adiponectin levels between healthy controls and patients with simple steatosis. In contrast, leptin levels were elevated in NAFLD patients compared with nonsteatotic controls in a sample of obese children (57). Elevated leptin levels could further be used to predict significant fibrosis $(\mathrm{F} \geq 2)$, and classify NAFLD patients according to the level of fibrosis (65).

The relationship between interdisciplinary therapy consisting of various forms of physical exercise, clinical, nutritional and psychological interventions, and changes in serum adipokines levels was assessed in samples of obese adolescents. Improvements in the levels of noninvasive biomarkers and clinical characteristics of disease progression were observed, particularly among patients with NAFLD receiving multidisciplinary intervention $(32,61)$.

\section{USE OF INTRAGASTRIC BALLOON AND CHANGES IN ADIPOKINE LEVELS}

Combining the use of intragastric balloon with physical exercise led to more substantial weight loss, especially fat mass, in obese patients (66). Aside from weight loss, use of intragastric balloon (Bioenteric, Inamed Health, USA) led to improvement in the metabolic syndrome parameters such as diabetes mellitus, hypertension, dyslipidemia and fatty liver in compliant patients (67). After six months of intragastric balloon placement, $77.5 \%$ of subjects no longer met the diagnostic criteria for the metabolic syndrome in a sample of 40 previously overweight or obese patients with the metabolic syndrome. This procedure further reduced the percentage of truncal, android, gynoid and total fat $(\mathrm{P}=0.0001)$, and improved lung function parameters (68). In a small sample of obese patients treated with the BioEnterics intragastric balloon, the amount of weight loss experienced during the first month may be an important predictor of weight loss up to one year after balloon removal (18 months since baseline) (69). Table 4 describes the consequence of intragastric balloon placement in obese patients with NAFLD (70-73). Compared with baseline, anthropometric and biochemical measurements were improved at the time of balloon removal.

Studies show that weight loss is associated with histological improvements in obese NAFLD patients. The BioEnterics intragastric balloon has shown promising results in terms of weight loss in morbidly obese individuals and in individuals with treatment-resistant obesity. The balloon is filled with fluid to provide a sensation of satiety, thus reducing food ingestion during the time the balloon is used. Furthermore, it was conjectured that the short-term presence of the intragastric balloon would create behavioural routine whereby lower food amounts are consumed even after the balloon is removed, usually within six months of placement (70).

BioEnterics intragastric balloon placement was associated with improved eating patterns (74). Treatment with intragastric balloon for six months followed by 12 months of behavioural modification was associated with more pronounced weight loss and reversal of the metabolic syndrome compared with 12 months of behavioural modification alone in a small sample of obese adults (75). A reduction in hunger and an increase in sense of satiety was observed among nine obese children using a gastric balloon system (Obalon, Obalon Therapeutics, USA) for three months (73).

\section{Leptin}

Treatment with intragastric balloon placement, low-calorie diet $(1500 \mathrm{kcal} /$ day $)$ and physical exercise was associated with decreased leptin levels, which correlated with weight loss (76). There were significant changes in leptin levels in both patient groups throughout the 12 -month study period in a sample of 43 obese Caucasian patients 
TABLE 3

Adipokine levels in children and adolescents

\begin{tabular}{|c|c|c|}
\hline Study and sample population & Changes in adipokines & Associations and diagnostic performance \\
\hline $\begin{array}{l}\text { de Piano et al (32) } \\
58 \text { postpubertal obese } \\
\text { adolescents randomly assigned } \\
\text { to AT or AT + RT } \\
\text { AT group: } 15 \text { patients without } \\
\text { NAFLD and } 14 \text { with NAFLD } \\
\text { AT + RT group: } 15 \text { patients } \\
\text { without NAFLD and } 14 \text { with } \\
\text { NAFLD }\end{array}$ & $\begin{array}{l}\text { Change in adiponectin at } 1 \text { year: }-0.13 \pm 1.73 \text { in AT without } \\
\text { NAFLD, }-0.13 \pm 2.78 \text { in AT with NAFLD, } 2.57 \pm 2.50 \text { in AT + RT } \\
\text { without NAFLD }(P<0.05 \text { vs AT), } 2.69 \pm 2.54 \mu \mathrm{g} / \mathrm{mL} \text { in AT + RT } \\
\text { with NAFLD ( } P<0.05 \text { vs AT) } \\
\text { Change in leptin at } 1 \text { year: }-7.13 \pm 12.68 \text { in AT without NAFLD, } \\
-12.17 \pm 17.22 \text { in AT with NAFLD, }-9.19 \pm 13.61 \text { in AT + RT } \\
\text { without NAFLD ( }<<0.05 \text { vs AT), }-11.95 \pm 13.08 \mu \mathrm{g} / \mathrm{mL} \text { in AT + RT } \\
\text { with NAFLD } \\
\text { Change in adiponectin/leptin at } 1 \text { year: } 0.72 \pm 1.56 \text { in AT without } \\
\text { NAFLD, } 1.02 \pm 1.19 \text { in AT with NAFLD, } 0.68 \pm 1.30 \text { in AT + RT } \\
\text { without NAFLD, } 0.40 \pm 1.85 \text { in AT + RT with NAFLD }\end{array}$ & $\mathrm{n} / \mathrm{a}$ \\
\hline $\begin{array}{l}\text { Boyraz et al (57) } \\
\text { Group I: } 63 \text { obese children } \\
\text { with liver steatosis } \\
\text { Group II: } 12 \text { obese children } \\
\text { with elevated serum ALT } \\
\text { activity from group I }\end{array}$ & $\begin{array}{l}\text { Mean adiponectin: } 2.7 \pm 0.7 \text { in group I, } 2.5 \pm 0.4 \text { in group II } \\
\text { and } 4.7 \pm 1.1 \mu \mathrm{g} / \mathrm{mL} \text { in group III ( } P<0.001 \text { vs group I and } \\
P<0.001 \mathrm{vs} \text { group II) } \\
\text { Mean resistin: } 8.5 \pm 3.2 \text { in group I, } 8.5 \pm 3.2 \text { in group II and } \\
15.0 \pm 3.9 \mathrm{ng} / \mathrm{mL} \text { in group III }(P<0.001 \mathrm{vs} \mathrm{group} \mathrm{I} \mathrm{and} \\
P<0.001 \mathrm{vs} \text { group II) }\end{array}$ & $\begin{array}{l}\text { Adiponectin: sensitivity of } 84.21 \% \text { and specificity of } 63.64 \% \\
\text { for advanced liver steatosis at cut-off } 2.56 \mu \mathrm{g} / \mathrm{mL} \\
\text { Resistin: sensitivity of } 36.8 \% \text { and specificity of } 95.5 \% \\
\text { for advanced liver steatosis at cut-off } 5.2 \mathrm{ng} / \mathrm{mL} \\
\text { RBP4: sensitivity of } 84.20 \% \text { and a specificity of } 68.20 \% \\
\text { for advanced liver steatosis at cut-off } 35 \mu \mathrm{g} / \mathrm{mL}\end{array}$ \\
\hline $\begin{array}{l}\text { Koot et al (58) } \\
119 \text { severely obese children } \\
\text { (47\% prevalence of steatosis) }\end{array}$ & $\begin{array}{l}\text { Mean adiponectin: } 7.8 \pm 2.8 \mu \mathrm{g} / \mathrm{mL} \text { at baseline } \\
\text { Mean leptin: } 33.9 \pm 632.4 \text { at baseline }\end{array}$ & $\begin{array}{l}\text { Adiponectin not associated with steatosis in univariate analysis } \\
\text { (OR } 0.96[95 \% \mathrm{Cl} 0.84-1.09] ; \mathrm{P}=0.52) \\
\text { Leptin associated with steatosis in multivariate analysis } \\
\text { (OR } 1.04[95 \% \mathrm{Cl} 1.01-1.09] ; \mathrm{P}=0.03 \text { ) }\end{array}$ \\
\hline $\begin{array}{l}\text { Pacifico et al }(59) \\
44 \text { obese children with NAFLD } \\
44 \text { obese children without } \\
\text { NAFLD }\end{array}$ & $\begin{array}{l}\text { Leptin: mean } 19.5 \text { in NAFLD vs } 20.8 \mu \mathrm{g} / \mathrm{L} \text { in non-NAFLD } \\
\text { Adiponectin: mean } 9.0 \text { in NAFLD vs } 12.9 \mu \mathrm{g} / \mathrm{L} \text { in non-NAFLD } \\
(P<0.05)\end{array}$ & \\
\hline
\end{tabular}

AT Aerobic training; ALT Alanine aminotransferase; n/a Not applicable; NAFLD Nonalcoholic fatty liver disease; PAl-1 Plasminogen activator inhibitor-1; RBP4 Retinol-binding protein-4; RT Resistance training; vs Versus

(divided into morbidly and nonmorbidly obese based on a BMI cut-off of $40 \mathrm{~kg} / \mathrm{m}^{2}$ ) (77). Throughout the study period, leptin levels remained below baseline values. Leptin levels decreased beginning at month 1 (mean $21.1 \mathrm{ng} / \mathrm{mL}$ versus mean $28.7 \mathrm{ng} / \mathrm{mL}$ at baseline), with slight oscillations thereafter (mean $17.4 \mathrm{ng} / \mathrm{mL}$ to $19.0 \mathrm{ng} / \mathrm{mL}$ ) among morbidly obese individuals (BMI $\geq 40 \mathrm{~kg} / \mathrm{m}^{2}$ ). Leptin levels were lower at months 1 and 6 (mean $11.8 \mathrm{ng} / \mathrm{mL}$ and $10.5 \mathrm{ng} / \mathrm{mL}$, respectively, versus mean $25.1 \mathrm{ng} / \mathrm{mL}$ at baseline) among obese individuals (BMI $<40 \mathrm{~kg} / \mathrm{m}^{2}$ ), with a slight rise approaching month 12 (mean $17.5 \mathrm{ng} / \mathrm{mL}$ ) (77). Leptin significantly decreased during the first month in another small sample of obese patients undergoing intragastric balloon placement (median $67.1 \mathrm{ng} / \mathrm{dL}$ at baseline, 53.7 at month 1, 39.3 at month 3 and $26.5 \mathrm{ng} / \mathrm{dL}$ at month 6; $\mathrm{P}=0.0353)(78)$.

Leptin levels decreased throughout the study in the balloon group $(\mathrm{P}=0.05$ at month 6 and $\mathrm{P}=0.04$ at month 10 versus baseline) and remained relatively stable in the control group among obese patients treated with the BioEnterics intragastric balloon, low-calorie diet (1500 kcal/day) and physical exercise, or low-calorie diet and physical exercise alone (76). Leptin levels decreased throughout the study period in a small sample of nonmorbidly obese patients with intragastric balloon $(27.8 \pm 3.7 \mathrm{ng} / \mathrm{mL}$ at baseline versus $18.7 \pm 2.7 \mathrm{ng} / \mathrm{mL}$ at month 6 ; $\mathrm{P}=0.024)$ (79). Leptin was significantly decreased $(30.4 \pm 17.2 \mu \mathrm{g} / \mathrm{L}$ versus $14.9 \pm 15.5 \mu \mathrm{g} / \mathrm{L} ; \mathrm{P}<0.001)$ after six months in 22 obese individuals with the balloon (80).

\section{Ghrelin}

Ghrelin is a peptide hormone that stimulates food intake. Abnormalities in meal-related peptides, such as ghrelin, are associated with binge eating disorders (81). In normal individuals, ghrelin levels rise before meals and fall following meals. However, in obese individuals, ghrelin 


\section{TABLE 4}

\section{Intragastric balloon placement}

\begin{tabular}{|c|c|}
\hline Study and sample population & Association with nonalcohoilic fatty liver disease \\
\hline $\begin{array}{l}\text { Lee et al }(70) \\
18 \text { obese NASH patients }\end{array}$ & $\begin{array}{l}\text { Balloon: reductions in mean body mass index }\left(1.52 \mathrm{~kg} / \mathrm{m}^{2} \mathrm{vs} 0.8 \mathrm{~kg} / \mathrm{m}^{2} ; \mathrm{P}=0.0008\right) \text { and median NAFLD activity scores } \\
(2 \text { vs } 4 ; \mathrm{P}=0.0 .03) \text {, with a trend toward improved steatosis scores }(\mathrm{P}=0.075) \text { compared with sham }\end{array}$ \\
\hline $\begin{array}{l}\text { Bioenterics* intragastric balloon } \\
+ \text { exercise }+ \text { diet for } 6 \text { months } \\
(n=8)\end{array}$ & $\begin{array}{l}\text { No differences with respect to lobular inflammation, hepatocellular ballooning or fibrosis scores } \\
\text { No significant changes in AST or ALT levels }\end{array}$ \\
\hline $\begin{array}{l}\text { Sham balloon }(500 \mathrm{~mL} \text { of } \\
\text { saline solution) + exercise } \\
+ \text { diet }(n=10)\end{array}$ & \\
\hline $\begin{array}{l}\text { Tai et al }(71) \\
28 \text { obese patients } \\
\text { Bioenterics* intragastric balloon } \\
\text { placement for } 6 \text { monhts }\end{array}$ & $\begin{array}{l}\text { Improvement in body mass index (mean } 32.4 \pm 3.7 \mathrm{~kg} / \mathrm{m}^{2} \text { vs } 28.5 \pm 3.7 \mathrm{~kg} / \mathrm{m}^{2} ; \mathrm{P}<0.01 \text { ), waist circumference }(\mathrm{mean} 101.9 \pm 8.9 \mathrm{~cm} \\
\text { vs } 90.6 \pm 9.3 \mathrm{~cm} ; \mathrm{P}<0.01 \text { ), glucose (median } 93.5 \mathrm{mg} / \mathrm{dL} \text { vs } 91.0 \mathrm{mg} / \mathrm{dL} ; \mathrm{P}<0.01) \text {, AST level (median } 33.0 \mathrm{IU} / \mathrm{L} \text { vs } 23.0 \mathrm{IU} / \mathrm{L} ; \\
\mathrm{P}<0.01 \text { ), ALT level (median } 49.0 \mathrm{IU} / \mathrm{L} \text { vs } 22.0 \mathrm{IU} / \mathrm{L} ; \mathrm{P}<0.01 \text { ), triglyceride (median } 149.0 \mathrm{mg} / \mathrm{dL} \text { vs } 88.5 \mathrm{mg} / \mathrm{dL} ; \mathrm{P}<0.01 \text { ), cho- } \\
\text { lesterol (median } 200.0 \text { vs } 186 \mathrm{mg} / \mathrm{dL} ; \mathrm{P}=0.13 \text { ), high-density lipoprotein-cholesterol (median } 45.0 \mathrm{vs} 52.0 \mathrm{mg} / \mathrm{dL} ; \mathrm{P}=0.01 \text { ), low- } \\
\text { density lipoprotein-cholesterol (median } 119.5 \mathrm{vs} 114.0 \mathrm{mg} / \mathrm{dL} ; \mathrm{P}=0.03 \text { ), the metabolic syndrome }(64.3 \% \mathrm{vs} 32.1 \% ; \mathrm{P}=0.01) \text { at } \\
6 \text { months compared with baseline }\end{array}$ \\
\hline
\end{tabular}

Folini et al (72)

40 obese subjects

Intragastric balloon or gastric banding: lower ALT $(P=0.02)$, AST $(P=0.03)$, total cholesterol $(P=0.007)$, low-density lipoprotein-

Intragastric balloon or gastric

banding for 6 months $(n=24)$

Diet for 6 months $(n=16)$

Nobili et al (73)

9 obese children

Obalon ${ }^{\dagger}$ balloon for 3 months

cholesterol $(P=0.03)$ and fat-free mass $(P=0.01)$ at the end of the study compared with diet

Significant improvements in ALT, total and low-density lipoprotein cholesterol, insulin, HOMA-IR and uric acid levels No significant changes in ultrasonographic examination

*Inamed Health, USA; †Obalon Therapeutics, USA. ALT Alanine aminotransferase; AST Aspartate aminotransferase; HOMA-IR Homeostasis model assessmentinsulin resistance; NAFLD Nonalcoholic fatty liver disease; NASH Nonalcoholic steatohepatitis; vs Versus

levels are lower than in healthy individuals, a phenomenon believed to be the result rather than the cause of overeating (81). Obesity was shown to actually lead to lower ghrelin levels. Ghrelin significantly increased $(240.5 \pm 101.5 \mu \mathrm{g} / \mathrm{L}$ versus $335.8 \pm 149.2 \mu \mathrm{g} / \mathrm{L} ; \mathrm{P}<0.002)$ after six months in 22 obese individuals with intragastric balloon treatment (80). Among obese individuals (BMI $<40 \mathrm{~kg} / \mathrm{m}^{2}$ ), ghrelin levels peaked around month 3 (mean $1346.2 \mathrm{pg} / \mathrm{mL}$ versus mean $958.3 \mathrm{pg} / \mathrm{mL}$ at baseline), and then decreased steadily to near baseline levels by month 12 (mean $922.6 \mathrm{pg} / \mathrm{mL}$ ). Ghrelin levels remained relatively stable through the first six months of the study among morbidly obese individuals (BMI $\geq 40 \mathrm{~kg} / \mathrm{m}^{2}$ ), with a drop toward month 12 (mean $742.6 \mathrm{pg} / \mathrm{mL}$ versus mean $948.3 \mathrm{pg} / \mathrm{mL}$ at baseline) (77).

Blood ghrelin levels were measured every $15 \mathrm{~min}$ for $1 \mathrm{~h}$ after breakfast at the start of treatment, after 13 weeks and after 26 weeks in a sample of 40 obese patients randomly assigned to a 13-week period of sham or balloon, followed by 13 weeks of balloon. There were no differences in plasma ghrelin levels (either fasting or trough levels) between groups. Ghrelin levels did not change from baseline to end of treatment (mean fasting $725.9 \pm 152.2 \mathrm{pg} / \mathrm{mL}$ and trough $596.0 \pm 105.3 \mathrm{pg} / \mathrm{mL}$ at baseline versus mean fasting $773.4 \pm 113.8 \mathrm{pg} / \mathrm{mL}$ and trough $669.3 \pm 128.4 \mathrm{pg} / \mathrm{mL}$ at six months) despite weight loss (82).

Weight loss was more pronounced in the balloon group at six months $(17.1 \pm 8.0 \mathrm{~kg}$ versus $3.2 \pm 6.4 \mathrm{~kg})$ in a sample of 21 obese subjects who were treated with a BioEnterics intragastric balloon, lowcalorie diet $(1500 \mathrm{kcal})$ and physical exercise, and 15 controls treated with low-calorie diet and physical exercise alone. In the balloon group, ghrelin levels increased at one month $(\mathrm{P}=0.006$ versus baseline) and slowly decreased thereafter until they approached baseline levels at three months after balloon removal. Ghrelin levels were relatively stable throughout the study in the control group. Based on these findings, balloon treatment is associated with transiently elevated ghrelin levels in obese patients (76).

Weight reduction was correlated with plasma ghrelin levels in 17 nonmorbidly obese patients. Plasma ghrelin levels decreased throughout the study $(3.2 \pm 0.4 \mathrm{ng} / \mathrm{mL}$ at baseline versus $1.9 \pm 0.1 \mathrm{ng} / \mathrm{mL}$ at month $6 ; \mathrm{P}=0.021$ ). In this study, weight loss associated with intragastric balloon correlated with plasma ghrelin variations (79). Ghrelin was significantly increased $(240.5 \pm 101.5 \mu \mathrm{g} / \mathrm{L}$ versus $335.8 \pm 149.2 \mu \mathrm{g} / \mathrm{L}$;
$\mathrm{P}<0.002$ ) after six months in 22 obese individuals with intragastric balloon placement $(80)$.

Weight loss occurred in both groups in a randomized, doubleblinded, sham-controlled trial of four months' duration in morbidly obese patients treated with either intragastric balloon placement or sham operation. However, there were no significant differences between the balloon group and the control group in terms of degree of weight loss. These changes were not mediated by changes in plasma ghrelin levels, because ghrelin levels did not fluctuate between fasting and postprandial conditions, and between the two treatments (mean fasting ghrelin $934.4 \pm 199.2 \mathrm{pg} / \mathrm{mL}$ at baseline versus $947.1 \pm 195.1 \mathrm{pg} / \mathrm{mL}$ at day 30 in the balloon group and mean fasting ghrelin $970.1 \pm 125.2 \mathrm{pg} / \mathrm{mL}$ at baseline versus $962.0 \pm 93.9 \mathrm{pg} / \mathrm{mL}$ at day 30 in the control group) (83).

\section{Adiponectin}

Adiponectin levels remained unchanged throughout the study in a sample of obese patients treated with intragastric balloon, low-calorie diet $(1500 \mathrm{kcal})$ and physical exercise (76). Adiponectin levels showed no significant difference in other small samples of obese patients undergoing intragastric balloon placement $(78,80)$. A transient increase in adiponectin levels was observed in obese controls treated with low-calorie diet $(1500 \mathrm{kcal})$ and physical exercise without intragastric balloon placement $(\mathrm{P}=0.045$ at six months versus baseline) (76). Adiponectin levels did not change significantly in another study (78). In contrast, Mion et al (79) found increasing adiponectin levels $(6.6 \pm 0.5 \mathrm{ng} / \mathrm{mL}$ at baseline versus $7.8 \pm 0.8 \mathrm{ng} / \mathrm{mL}$ at six months; $\mathrm{P}=0.037)$.

\section{BARIATRIC SURGERY AND CHANGES IN CIRCULATING LIVER ENZYME LEVELS, INFLAMMATORY MARKERS AND ADIPOKINE LEVELS An additional nonmedicinal intervention that can be used in NAFLD patients is bariatric surgery. Bariatric surgery is believed to ameliorate some of the abnormalities associated with NAFLD and, thus, lead to an improvement in NAFLD. This is believed to involve improvements in circulating liver enzyme levels, decreases in inflammatory marker lev- els, and changes in adipokines levels such as increases in adiponectin}


and decreases in leptin $(84,85)$. Improvements in steatosis, lobular inflammation, chronic portal inflammation and steatohepatitis were noted in a sample of NAFLD patients in which liver biopsy were analyzed pre- and postbariatric surgery (86). Roux-en-Y gastric bypass surgery was shown to decrease the metabolic syndrome parameters, as well as the prevalence of comorbidities associated with obesity, including fatty liver and steatosis. This effect was observed in both sexes and among all individuals 18 to 65 years of age (87). The effects of bariatric surgery in obese populations, with or without NAFLD/NASH, are described in Table 5 (88-97).

\section{Liver enzymes}

The effects of bariatric surgery on circulating levels of liver enzymes were assessed in several studies (88-93). ALT, AST and gamma-glutamyl transpeptidase $(\gamma$-GTP) levels are generally lower at follow-up (six to 12 months after the surgical intervention) compared with baseline levels (ie, before surgery) in samples of obese patients $(90,93,98)$. Lower serum AST and ALT levels were maintained at two and 10 years followup in a large sample of obese subjects who underwent bariatric surgery. ALT reduction was proportional to weight loss (99). In another study, bariatric surgery led to decreased $\gamma$-GTP levels at follow-up, but had no effects on ALT and AST levels (88). Elsewhere, near normalization of ALT was observed in a sample of morbidly obese patients undergoing bariatric surgery, while mean serum $\gamma$-GTP levels decreased to levels below those of controls. No significant differences were observed in AST levels between controls and NAFLD patients, and between levels before and after bariatric surgery within the NAFLD subsample $(91,92)$.

Roux-en-Y gastric bypass was associated with improved NAFLD parameters, and these effects were maintained for at least five years. Decreased AST levels following Roux-en-Y gastric bypass were observed in association with a decrease in NAFLD fibrosis score $(1.142 \pm 1.261$ at baseline versus $0.066 \pm 1.027$ at 12 months; $\mathrm{P}=0.0394$ ) in a large sample of 1236 obese patients (98). Bariatric surgery produced significant histopathological improvements in terms of steatosis $(\mathrm{P}<0.001)$, ballooning degeneration $(\mathrm{P}<0.001)$, Mallory-Denk hyaline bodies $(\mathrm{P}=0.005)$, glycogen nuclei $(\mathrm{P}=0.001)$, lobular inflammation $(\mathrm{P}<0.001)$, portal inflammation $(\mathrm{P}=0.005)$ and fibrosis $(\mathrm{P}<0.001)(88)$.

\section{Adipokines}

In general, serum adiponectin levels are lower $(2.2 \pm 1.7 \mu \mathrm{g} / \mathrm{mL}$ in patients versus $4.1 \pm 2.5 \mu \mathrm{g} / \mathrm{mL}$ in control; $\mathrm{P}<0.001$ ) and serum leptin levels are elevated $(28.1 \pm 18.4 \mathrm{ng} / \mathrm{mL}$ in patients versus $4.7 \pm 3.9 \mathrm{ng} / \mathrm{mL}$ in control; $\mathrm{P}<0.001)$ in obese patients compared with nonobese controls (100). Bariatric surgery increases adiponectin levels and decreases leptin levels compared with presurgery levels. For example, mean serum leptin level was elevated, while mean serum adiponectin level was lower in a small sample of obese patients undergoing laparoscopic sleeve gastrectomy compared with nonobese controls. Leptin levels decreased, while adiponectin levels increased within one month following this intervention. These changes were maintained six months after the procedure (100). Roux-en-Y gastric bypass led to decreasing leptin levels in a small sample of morbidly obese patients (91). Adiponectin levels increased and leptin levels decreased in a timedependent manner through month 12 in a sample of obese patients undergoing laparoscopic adjustable gastric banding (93). In another study, normalization of both adiponectin and leptin levels to values similar to those observed in controls were observed in morbidly obese patients following bariatric surgery (92).

Decreased adiponectin levels at baseline were observed in other samples of obese patients compared with nonobese controls. Following bariatric surgery, adiponectin levels increased in a time-dependent manner $(90,94,96,97,101)$. Interestingly, no further increases were observed beyond four weeks in a sample of 108 morbidly obese NAFLD patients undergoing bariatric surgery. However, adiponectin levels continued to increase through six months in NASH patients (102).

Bechmann et al (64) reported that obesity is negatively correlated with adiponectin levels, while adiponectin levels are inversely correlated with the NAFLD activity score. Low adiponectin levels $(<13.5 \mathrm{mg} / \mathrm{L}$ in one study and $<23 \mathrm{mg} / \mathrm{L}$ in another study) were a strong predictor of NAFLD severity elsewhere $(95,103)$. Adiponectin levels were lower in NASH compared with simple steatosis. Adiponectin levels further decreased progressively with increasing steatosis severity and with more severe lobular inflammatory activity (95). Lower adiponectin levels were also found in patients with fibrosis compared with those without fibrosis (101).

Leptin levels increased in parallel with increasing steatosis severity and with the severity of lobular inflammatory activity. A trend for higher leptin levels in patients with more advanced fibrosis was also noted (95). Leptin levels did not correlate with fibrosis in another study (101).

Other adipokines measured in NAFLD patients include ghrelin, visfatin and resistin. Ghrelin levels were correlated with lobular inflammation but not with steatosis severity, and were an independent predictor of NASH $(95,104)$. Ghrelin levels decreased significantly in a sample of obese patients who underwent laparoscopic sleeve gastrectomy and dieatry changes $(127.5 \pm 96.9 \mathrm{ng} / \mathrm{L}$ at baseline, $62.6 \pm 60.9 \mathrm{ng} / \mathrm{L}$ at six months and $87.5 \pm 59.1 \mathrm{ng} / \mathrm{L}$ at 12 months) (105). Mean serum visfatin levels decreased at six weeks' follow-up in a small sample of severely obese patients undergoing gastric bypass (94). Serum resistin levels were elevated at six months, but decreased to below baseline levels by 12 months after laparoscopic adjustable gastric banding (93).

\section{Inflammatory markers}

Elevated mean blood high-sensitivity CRP and interleukin (IL)-6 levels were present at baseline among obese patients versus lean controls (CRP: $26.19 \pm 23.17 \mathrm{~g} / \mathrm{L}$ versus $1.71 \pm 2.27 \mathrm{~g} / \mathrm{L}$, respectively; $\mathrm{P}<0.001$, and IL-6: $3.84 \pm 1.67 \mathrm{pg} / \mathrm{mL}$ versus $0.92 \pm 0.47 \mathrm{pg} / \mathrm{mL}$, respectively; $\mathrm{P}<0.001)$. IL-6 and high-sensitivity CRP levels decreased by three months after bariatric surgery (97). Significant decreases in CRP levels were observed after six months in a sample of obese patients undergoing laparoscopic adjustable gastric banding. These differences were even more pronounced at 12 months (93). Serum IL-6 levels decreased within six months of bariatric surgery in a small sample of severely obese patients. Similarly, hepatic IL-6 messenger RNA expression was decreased at six months (106). IL-18, soluble tumour necrosis factor (TNF) receptor 2 and CRP levels decreased at 12 months' follow-up compared with baseline in a small sample of morbidly obese subjects undergoing gastric bypass (96).

Elevated mean TNF- $\alpha$ levels at baseline were observed in a sample of morbidly obese patients compared with lean controls $(2.10 \pm 1.86 \mathrm{pg} / \mathrm{mL}$ versus $0.86 \pm 0.67 \mathrm{pg} / \mathrm{mL} ; \mathrm{P}<0.001)$. TNF- $\alpha$ levels initially increased at three months, but stabilized to near-baseline levels by month 12 after bariatric surgery in one study (97). Significant decreases in TNF- $\alpha$ were observed after six months elsewhere (93). Serum TNF- $\alpha$ levels were undetectable in another study, while hepatic TNF- $\alpha$ messenger RNA expression did not change (106).

\section{FRUCTOSE}

Fructose is found in a wide variety of processed foods and beverages (107). A relationship is believed to exist between high fructose consumption and NAFLD development and progression. While providing fructose as a dietary supplement for seven days in children of type 2 diabetes patients or controls, Lê et al (108) observed that a diet high in fructose is associated with dyslipidemia, especially in individuals with a family history of type 2 diabetes. A high-fructose diet significantly increased intrahepatocellular lipids, intramyocellular lipids, very low-density lipoprotein-triacylglycerols and fasting hepatic glucose output in both groups. However, higher intrahepatocellular lipids and total triacylglycerols, and lower whole-body insulin sensitivity occurred in children with a family history of type 2 diabetes (108). High acute fructose consumption from soft drinks further led to elevated endotoxin levels, which are associated with the presence of hepatic steatosis. High chronic fructose consumption was associated with persistently elevated endotoxin levels, suggesting that the association between fructose consumption and liver steatosis is mediated, at least in part, by endotoxin (109). 


\section{Neuman et al}

\section{TABLE 5}

Circulating liver enzyme levels, adipokines and inflammatory markers in patients undergoing bariatric surgery

\begin{tabular}{ll}
\hline Study; sample population & Changes following bariatric surgery \\
\hline Vargas et al $(88) ;$ & Mean $( \pm \mathrm{SD})$ serum AST: $0.35 \pm 0.09 \mu \mathrm{kat} / \mathrm{L}$ during presurgery vs $0.36 \pm 0.17 \mu \mathrm{kat} / \mathrm{L}$ after surgery $(\mathrm{P}=0.862)$ \\
26 morbidly obese patients & Mean serum ALT: $0.49 \pm 0.20 \mu \mathrm{kat} / \mathrm{L}$ during presurgery vs $0.37 \pm 0.31 \mu \mathrm{kat} / \mathrm{L}$ after surgery $(\mathrm{P}=0.143)$ \\
$\begin{array}{c}(96.1 \% \text { had NASH) } \\
\text { undergoing Roux-en-Y }\end{array}$ & Mean serum $\mathrm{Y}-\mathrm{GTP}: 40.2 \pm 17.4$ during presurgery vs $19.2 \pm 12.8 \mathrm{IU} / \mathrm{L}$ after surgery $(\mathrm{P}<0.001)$
\end{tabular}
gastric bypass with a modified Fobi-Capella technique (follow-up after $16.3 \pm 3$ months)

Cazzo et al (89);

63 obese subjects undergoing Roux-en-Y gastric bypass surgery

Carazo et al (90);

60 morbidly obese patients undergoing bariatric surgery

Mean ( \pm SD) serum ALT: $30.7 \pm 17.1 \mathrm{mg} / \mathrm{dL}$ at baseline vs $20.7 \pm 7.2 \mathrm{mg} / \mathrm{dL}$ at month $12(P<0.0001)$ Mean serum AST: $25.7 \pm 10.6 \mathrm{mg} / \mathrm{dL}$ at baseline vs $21.2 \pm 5.4 \mathrm{mg} / \mathrm{dL}$ at month $12(P=0.0005)$

Mean ( \pm SD) plasma AST: $29.8 \pm 3.3 \mathrm{IU} / \mathrm{L}$ before surgery vs $20.4 \pm 1.0 \mathrm{IU} / \mathrm{L}$ at month $12(P=0.0070)$

Mean plasma ALT: $31.0 \pm 3.1 \mathrm{IU} / \mathrm{L}$ before surgery vs $19.3 \pm 1.5 \mathrm{IU} / \mathrm{L}$ at month $12(P=0.001)$

Mean plasma Y-GTP: $37.7 \pm 8.0 \mathrm{IU} / \mathrm{L}$ before surgery vs $17.5 \pm 2.1 \mathrm{IU} / \mathrm{L}$ at month $12(\mathrm{P}<0.001)$

Mean plasma adiponectin: $39.9 \pm 6.0 \mu \mathrm{g} / \mathrm{mL}$ before surgery vs $60.0 \pm 2.1 \mu \mathrm{g} / \mathrm{mL}$ at month $12(P=0.002)$

Tai et al (91);

21 morbidly obese patients undergoing Roux-en-Y gastric bypass

Median serum AST: $27.0 \mathrm{IU} / \mathrm{L}$ before surgery vs $27.0 \mathrm{IU} / \mathrm{L}$ at month $12(P=0.66)$

Median serum ALT: $34.0 \mathrm{IU} / \mathrm{L}$ before surgery vs $24.0 \mathrm{IU} / \mathrm{L}$ at month $12(P<0.01)$

Median serum Y-GTP: $28.0 \mathrm{IU} / \mathrm{L}$ before surgery vs $12.0 \mathrm{IU} / \mathrm{L}$ at month $12(\mathrm{P}<0.01)$

Median serum leptin: $29.0 \mu \mathrm{g} / \mathrm{L}$ before surgery vs $4.1 \mu \mathrm{g} / \mathrm{L}$ at month $12(P<0.01)$

Felipo et al (92);

47 mordibly obese patients undergoing bariatric surgery (evaluated before and $18 \pm 5$ months after surgery) 45 controls

Mean ( \pm SD) serum AST: $20 \pm 4.0 \mathrm{IU} / \mathrm{L}$ in controls, $23.5 \pm 15 \mathrm{IU} / \mathrm{L}$ in simple steatosis patients before surgery, $23 \pm 95 \mathrm{IU} / \mathrm{L}$ in simple steatosis patients after surgery, $24.5 \pm 16 \mathrm{IU} / \mathrm{L}$ in NASH patients before surgery and $20.5 \pm 6 \mathrm{IU} / \mathrm{L}$ in NASH patients after surgery Mean serum ALT: $17 \pm 6.0 \mathrm{IU} / \mathrm{L}$ in controls, $31 \pm 17 \mathrm{IU} / \mathrm{L}$ in simple steatosis patients before surgery $(\mathrm{P}<0.05 \mathrm{vs}$ control) , $23 \pm 17 \mathrm{IU} / \mathrm{L}$ in simple steatosis patients after surgery, $37 \pm 16 \mathrm{IU} / \mathrm{L}$ in NASH patients before surgery $(\mathrm{P}<0.05 \mathrm{vs}$ control) and $20 \pm 12 \mathrm{IU} / \mathrm{L}$ in NASH patients after surgery

Mean serum Y-GTP: $40 \pm 10 \mathrm{IU} / \mathrm{L}$ in controls, $39 \pm 26 \mathrm{IU} / \mathrm{L}$ in simple steatosis patients before surgery, $19 \pm 15 \mathrm{IU} / \mathrm{L}$ in simple steatosis patients after surgery ( $P<0.05$ vs before surgery), $45 \pm 19 \mathrm{IU} / \mathrm{L}$ in NASH patients before surgery and $23 \pm 11 \mathrm{IU} / \mathrm{L}$ in NASH patients after surgery $(P<0.05$ vs before surgery)

Mean serum adiponectin: $11 \pm 4 \mathrm{i} \mu \mathrm{g} / \mathrm{mL} \mathrm{n}$ controls, $7 \pm 2 \mu \mathrm{g} / \mathrm{mL}$ in simple steatosis patients before surgery ( $P<0.05 \mathrm{vs}$ control), $16 \pm 10 \mu \mathrm{g} / \mathrm{mL}$ in simple steatosis patients after surgery ( $P<0.001 \mathrm{vs}$ before surgery), $6 \pm 2 \mu \mathrm{g} / \mathrm{mL}$ in NASH patients before surgery $(\mathrm{P}<0.05$ vs control) and $12 \pm 7 \mu \mathrm{g} / \mathrm{mL}$ in $\mathrm{NASH}$ patients after surgery ( $\mathrm{P}=0.008$ vs before surgery)

Mean serum leptin: $13 \pm 9 \mathrm{ng} / \mathrm{mL}$ in controls, $69 \pm 25 \mathrm{ng} / \mathrm{mL}$ in simple steatosis patients before surgery $(P<0.001 \mathrm{vs}$ control), $20 \pm 18 \mathrm{ng} / \mathrm{mL}$ in simple steatosis patients after surgery ( $P<0.001$ vs before surgery), $54 \pm 22 \mathrm{ng} / \mathrm{mL}$ in NASH patients before surgery $(P<0.001$ vs control) and $24 \pm 11 \mathrm{ng} / \mathrm{mL}$ in NASH patients after surgery $(P<0.001$ vs before surgery)

Moschen et al (93); 30 severely obese patients undergoing laparoscopic adjustable gastric banding
Mean $( \pm \mathrm{SD})$ serum AST: $30.1 \pm 2.6 \mathrm{IU} / \mathrm{L}$ at baseline, $26.8 \pm 2.4 \mathrm{IU} / \mathrm{L}$ at month $6(P<0.05)$ and $23.9 \pm 1.2 \mathrm{IU} / \mathrm{L}$ at month $12(P<0.05)$ Mean serum ALT: $35.1 \pm 5.6 \mathrm{IU} / \mathrm{L}$ at baseline, $25.4 \pm 3.5 \mathrm{IU} / \mathrm{L}$ at month $6(P<0.05)$ and $20.8 \pm 1.6 \mathrm{IU} / \mathrm{L}$ at month $12(P<0.01)$ Mean serum Y-GTP: $34.5 \pm 4.0 \mathrm{IU} / \mathrm{L}$ at baseline, $26.1 \pm 2.4 \mathrm{IU} / \mathrm{L}$ at month $6(\mathrm{P}<0.05)$ and $21.8 \pm 3.2 \mathrm{IU} / \mathrm{L}$ at $\mathrm{month} 12(\mathrm{P}<0.001)$ Mean serum adiponectin: $7.46 \pm 0.67 \mathrm{ng} / \mathrm{mL}$ at baseline, $8.65 \pm 0.84 \mathrm{ng} / \mathrm{mL}$ at month $6(P<0.05)$ and $8.95 \pm 0.81 \mathrm{ng} / \mathrm{mL}$ at $\mathrm{month} 12$ $(\mathrm{P}<0.01)$

Mean serum leptin: $27.4 \pm 1.38 \mu \mathrm{g} / \mathrm{mL}$ at baseline, $18.3 \pm 1.58 \mu \mathrm{g} / \mathrm{mL}$ at month $6(P<0.01)$ and $15.15 \pm 1.50 \mu \mathrm{g} / \mathrm{mL}$ at $\mathrm{month} 12(P<0.001)$ Mean serum resistin: $4.26 \pm 0.21 \mathrm{pg} / \mathrm{mL}$ at baseline, $5.18 \pm 0.26 \mathrm{pg} / \mathrm{mL}$ at month $6(P<0.05)$ and $3.37 \pm 0.19 \mathrm{pg} / \mathrm{mL}$ at $\mathrm{month} 12(P<0.01)$ Mean serum CRP: $0.86 \pm 0.08$ at baseline, $0.63 \pm 0.06$ at month $6(P<0.01)$ and $0.42 \pm 0.05 \mathrm{mg} / \mathrm{dL}$ at month $12(P<0.001)$ Mean serum TNF-a: $2.36 \pm 0.08 \mathrm{pg} / \mathrm{mL}$ at baseline, $1.77 \pm 0.06 \mathrm{pg} / \mathrm{mL}$ at month $6(P<0.05)$ and $0.8 \pm 0.03 \mathrm{pg} / \mathrm{mL}$ at $12(P<0.01)$

Hosseinzadeh-Attar et al (94); 35 severely obese patients undergoing gastric bypass

Machado et al (95);

Mean $( \pm S D)$ serum adiponectin: $36.5 \pm 11 \mathrm{ng} / \mathrm{mL}$ at baseline vs $41.3 \pm 11 \mathrm{ng} / \mathrm{mL}$ at week $6(P<0.01)$

Mean serum visfatin: $5 \pm 3.5 \mathrm{ng} / \mathrm{mL}$ at baseline vs $3.4 \pm 3.2 \mathrm{ng} / \mathrm{mL}$ at week $6(P<0.01)$

Mean ( \pm SD) serum adiponectin: $22.9 \pm 9.8 \mathrm{ng} / \mathrm{mL}$ overall, $16.2 \pm 6.6 \mathrm{ng} / \mathrm{mL}$ in NASH and $24.1 \pm 9.9 \mathrm{ng} / \mathrm{mL}$ in no NASH (P=0.014 vs NASH) 82 morbidly obese individuals Mean serum leptin: $20.1 \pm 6.9 \mathrm{ng} / \mathrm{mL}$ overall, $22.2 \pm 6.8 \mathrm{ng} / \mathrm{mL}$ in NASH and $19.1 \pm 6.9 \mathrm{ng} / \mathrm{mL}$ in no NASH $(P=0.291 \mathrm{vs} \mathrm{NASH})$ with biopsy-proven NAFLD Mean serum ghrelin: $19.9 \pm 11.5 \mathrm{pg} / \mathrm{mL}$ overall, $17.9 \pm 7.0 \mathrm{pg} / \mathrm{mL}$ in NASH and $20.2 \pm 12.3 \mathrm{pg} / \mathrm{mL}$ in no NASH $(\mathrm{P}=0.544 \mathrm{vs} \mathrm{NASH})$ $(13.4 \%$ had $\mathrm{NASH})$ undergoing bariatric surgery

Vilarrasa et al (96); 65 morbidly obese subjects undergoing gastric bypass

Illán-Gómez et al (97); 60 morbidly obese women undergoing gastric bypass 30 lean controls
Median serum adiponectin: $11.5 \mu \mathrm{g} / \mathrm{mL}$ at baseline vs $23.4 \mu \mathrm{g} / \mathrm{mL}$ at month $12(P<0.01)$

Median serum IL-18: $229.8 \mathrm{pg} / \mathrm{mL}$ at baseline vs $168.9 \mathrm{pg} / \mathrm{mL}$ at month $12(\mathrm{P}<0.01)$

Median serum STNFR1: $2.23 \mathrm{ng} / \mathrm{mL}$ at baseline vs $2.27 \mathrm{ng} / \mathrm{mL}$ at month 12

Median serum sTNFR2: $5.07 \mathrm{pg} / \mathrm{mL}$ at baseline vs $4.32 \mathrm{pg} / \mathrm{mL}$ at month $12(P<0.01)$

Median serum CRP: $7.9 \mathrm{mg} / \mathrm{L}$ at baseline vs $0.91 \mathrm{mg} / \mathrm{L}$ at month $12(P<0.01)$

Mean ( \pm SD) blood adiponectin: $5.82 \pm 2.93 \mu \mathrm{g} / \mathrm{mL}$ at baseline vs $7.64 \pm 3.74 \mu \mathrm{g} / \mathrm{mL}$ at month $3(P<0.001)$

Mean blood IL-6: $3.84 \pm 1.67 \mathrm{pg} / \mathrm{mL}$ at baseline vs $3.36 \pm 1.53 \mathrm{pg} / \mathrm{mL}$ at month $3(\mathrm{P}<0.01)$

Mean blood hsCRP: $26.19 \pm 23.17 \mathrm{~g} / \mathrm{L}$ at baseline vs $13.15 \pm 17.95 \mathrm{~g} / \mathrm{L}$ at month $3(P<0.001)$

ALT Alanine aminotransferase; AST Aspartate aminotransferase; CRP C-reactive protein; $\gamma$-GTP Gamma-glutamyl transpeptidase; hsCRP High-sensitivity CRP; IL Interleukin; NAFLD Nonalcoholic fatty liver disease; NASH Nonalcoholic steatohepatitis; sTNFR Soluble tumour necrosis factor receptor; vs Versus 
The association between elevated fructose consumption and NAFLD risk appears to be influenced by the actual amount of fructose consumed. Higher fructose intake (highest intake quartile: $29.2 \mathrm{~g} /$ day to $88.0 \mathrm{~g} /$ day) was not associated with NAFLD in an older Finnish population compared with lower fructose intake (lowest intake quartile: $2.2 \mathrm{~g} /$ day to $15.2 \mathrm{~g} /$ day). A possible explanation for these findings is that the levels of fructose intake were similar to the average population levels (110).

Because lifestyle interventions such as physical activity and dietary modifications represent an important first line of treatment in NAFLD patients, limiting fructose intake is an important area of research (111). Decreased fructose intake led to decreased intrahepatic fat content in a small sample of NAFLD patients at six months. However, this was coupled with reduced intake of glucose and sucrose, as well as reduced overall carbohydrate intake and energy consumption, such that no definitive conclusion can be drawn with regards to decreasing fructose alone (112).

In a recent study, consuming isocaloric diets with high fructose or high glucose content did not cause significant changes in the hepatic concentration of triacylglycerols or the serum levels of liver enzymes in a sample of healthy overweight men, with no differences between treatments. However, when high fructose or high glucose was administered as part of a hypercaloric diet, significant increases in these parameters occurred. This study suggests that overnutrition is associated with NAFLD risk factors, and not the levels of specific macronutrients (113). These findings are corroborated by a recent systematic review and meta-analysis (114) that showed no clear evidence that markers of hepatotoxicity are associated with excessive fructose intake per se, but rather with excessive energy intake. A separate systematic review and meta-analysis in controlled feeding trials shows that deriving a higher percentage of energy from fructose is not associated with a higher NAFLD risk in healthy controls. High fructose consumption coupled with excess energy intake is associated with elevated intrahepatocellular lipids and ALT levels, again suggesting that it is overnutrition rather than overconsumption of fructose that predisposes healthy individuals to NAFLD (115). Because restricting caloric intake, as a whole, is one of the main interventions aimed at weight loss in NAFLD patients, it is unclear what benefit, if any, would lower fructose intake have in the absence of lower overall energy intake (116).

Obesity was a risk factor for NAFLD at 17 years of age in a large sample of adolescents followed since birth. A higher energy-adjusted fructose intake at 14 years of age was associated with a higher risk of NAFLD at 17 years of age among obese adolescents, and this association was maintained after adjusting for confounding variables. This study shows that fructose rather than total sugar consumption is a risk factor for developing NAFLD in obese adolescents (117). Decreasing fructose intake reduced markers of liver dysfunction in a small sample of NAFLD children and adolescents (118). Sullivan et al (119) show in a small sample of NAFLD, obese controls and lean controls that fructose absorption and metabolism was more effective between NAFLD patients and lean control, but similar in NAFLD and obese controls. Children with NAFLD were more sensitive to dyslipidemia occurring in response to dietary fructose intake than children without NAFLD (120). While fructose alone is not generally believed to cause NAFLD development, fructose metabolites may influence NAFLD progression, and fructose intake may favour NAFLD progression on a background of pre-existing risk factors such as obesity, the metabolic syndrome or diabetes $(121,122)$. In view of the continued increase of the number of cases of NAFL-NASH, Chalasani et al (123) published the practice guidelines of the American Association for the Study of Liver Diseases, American College of Gastroenterology, and the American Gastroenterological Association.

\section{CONCLUSIONS}

The current practice for diagnosis of patients with NASH is to perform a liver biopsy and imaging. The present review defined novel criteria based on noninvasive biomarkers that optimized noninvasive diagnosis of liver disease in patients with NAFLD. Active inflammation of the liver (steatohepatitis) should be excluded first by blood tests that should assess adipokine and proinflammatory cytokine levels.

The clinical evaluation should also involve a personalized evaluation of laboratory data. Monitoring adipokine levels may inform the clinician on the changes in the severity of the liver disease in time as well as of the efficacy of the intervention. Aditionally, we suggest that these biomarkers may also be useful in improving the assessment of noninvasive fibrosis.

Dietary habits may promote steatohepatitis directly by modulating hepatic triglyceride accumulation and antioxidant activity, as well as indirectly by affecting insulin sensitivity and postprandial triglyceride metabolism. Our findings provide further rationale for more specific alimentary and physical activity interventions, particularly in nonobese, nondiabetic, normolipidemic NASH patients. In addition, the review highlights the importance of other procedures, such as gastric balloon and bariatric surgery, in improving ouotcomes. Finally, we recommend continued collaboration between clinicians and laboratory, which will benefit patients.

ACKNOWLEDGMENTS: In Vitro Drug Safety and Biotechnology and Mahaffy's innovative grant - Sunnybrook Health Science Centre, Toronto, Canada supported the work.

DISCLOSURES: All authors have read the Journal's policy on conflicts of interest and have none to declare. Also, all authors have read the Journal's policy on authorship and there are no conflicts of interest.

\section{REFERENCES}

1. Neuman MG, Hilzenrat N, Cohen L, Winkler RE, Nanau R. Multiple factors involved in nonalcoholic hepatitis pathogenesis. Int J Hepatol 2012;2012:429805.

2. Kleiner DE, Brunt EM, Van Natta M, et al. Design and validation of a histological scoring system for nonalcoholic fatty liver disease. Hepatology 2005;41:1313-21.

3. Neuman MG, French SW, French BA, et al. Alcoholic and nonalcoholic steatohepatitis. Exp Mol Pathol 2014;97:492-510.

4. Begriche K, Igoudjil A, Pessayre D, Fromenty B. Mitochondrial dysfunction in NASH: Causes, consequences and possible means to prevent it. Mitochondrion 2006;6:1-28.

5. Farrell GC, Larter CZ. Nonalcoholic fatty liver disease: From steatosis to cirrhosis. Hepatology 2006;43:S99-112.

6. Wong RJ, Aguilar M, Cheung R, et al. Nonalcoholic steatohepatitis is the second leading etiology of liver disease among adults awaiting liver transplantation in the United States. Gastroenterology 2014; pii: S0016-5085(14)01474-7. doi: 10.1053/j.gastro.2014.11.039.

7. Neuman MG. Apoptosis in diseases of the liver. Crit Rev Clin Lab Sci 2001;38:109-66.

8. Ben-Ari Z, Schmilovotz-Weiss H, Belinki A, et al. Circulating soluble cytochrome $\mathrm{C}$ in liver disease as a marker of apoptosis. J Intern Med 2003;254:168-75.

9. Browning JD, Horton JD. Molecular mediators of hepatic steatosis and liver injury. J Clin Invest 2004;114:147-52.

10. Reddy JK, Rao MS. Lipid metabolism and liver inflammation. II. Fatty liver disease and fatty acid oxidation. Am J Physiol Gastrointest Liver Physiol 2006;290:G852-8.

11. Weickert MO, Pfeiffer AF. Signalling mechanisms linking hepatic glucose and lipid metabolism. Diabetologia 2006;49:1732-41.

12. Miele L, Forgione A, La Torre G, et al. Serum levels of hyaluronic acid and tissue metalloproteinase inhibitor- 1 combined with age predict the presence of nonalcoholic steatohepatitis in a pilot cohort of subjects with nonalcoholic fatty liver disease. Transl Res 2009;154:194-201. 
13. Papandreou D, Karabouta Z, Pantoleon A, Rousso I. Investigation of anthropometric, biochemical and dietary parameters of obese children with and without non-alcoholic fatty liver disease. Appetite 2012;59:939-44.

14. Han JM, Jo AN, Lee SM, et al. Associations between intakes of individual nutrients or whole food groups and non-alcoholic fatty liver disease among Korean adults. J Gastroenterol Hepatol 2014;29:1265-72.

15. Targher G, Bertolini L, Scala L, et al. Associations between serum 25-hydroxyvitamin $\mathrm{D}_{3}$ concentrations and liver histology in patients with non-alcoholic fatty liver disease. Nutr Metab Cardiovasc Dis 2007;17:517-24.

16. Pirgon O, Cekmez F, Bilgin H, Eren E, Dundar B. Low 25-hydroxyvitamin D level is associated with insulin sensitivity in obese adolescents with non-alcoholic fatty liver disease. Obes Res Clin Pract 2013;7:e275-83.

17. Dasarathy J, Periyalwar P, Allampati S, et al. Hypovitaminosis D is associated with increased whole body fat mass and greater severity of non-alcoholic fatty liver disease. Liver Int 2014;34:e118-27.

18. Hao YP, Ma XJ, Luo YQ, et al. Serum vitamin D is associated with non-alcoholic fatty liver disease in Chinese males with normal weight and liver enzymes. Acta Pharmacol Sin 2014;35:1150-6.

19. Küçükazman M, Ata N, Dal KA, et al. The association of vitamin D deficiency with non-alcoholic fatty liver disease. Clinics (Sao Paulo) 2014;69:542-6.

20. Seo JA, Eun CR, Cho H, et al. Low vitamin D status is associated with nonalcoholic fatty liver disease independent of visceral obesity in Korean adults. PLoS One 2013;8:e75197.

21. Black LJ, Jacoby P, She Ping-Delfos WC, et al. Low serum 25-hydroxyvitamin D concentrations associate with non-alcoholic fatty liver disease in adolescents independent of adiposity. J Gastroenterol Hepatol 2014;29:1215-22.

22. Sharifi N, Amani R, Hajiani E, Cheraghian B. Does vitamin D improve liver enzymes, oxidative stress, and inflammatory biomarkers in adults with non-alcoholic fatty liver disease? A randomized clinical trial. Endocrine 2014;47:70-80.

23. Musso G, Gambino R, De Michieli F, et al. Dietary habits and their relations to insulin resistance and postprandial lipemia in nonalcoholic steatohepatitis. Hepatology 2003;37:909-16.

24. Oddy WH, Herbison CE, Jacoby P, et al. The Western dietary pattern is prospectively associated with nonalcoholic fatty liver disease in adolescence. Am J Gastroenterol 2013;108:778-85.

25. Da Silva HE, Arendt BM, Noureldin SA, Therapondos G, Guindi M, Allard JP. A cross-sectional study assessing dietary intake and physical activity in Canadian patients with nonalcoholic fatty liver disease vs healthy controls. J Acad Nutr Diet 2014;114:1181-94.

26. Mollard RC, Sénéchal M, MacIntosh AC, et al. Dietary determinants of hepatic steatosis and visceral adiposity in overweight and obese youth at risk of type 2 diabetes. Am J Clin Nutr 2014;99:804-12.

27. Veena J, Muragundla A, Sidgiddi S, Subramaniam S. Non-alcoholic fatty liver disease: Need for a balanced nutritional source. Br J Nutr 2014;112:1858-72.

28. Gerber L, Otgonsuren M, Mishra A, et al. Non-alcoholic fatty liver disease (NAFLD) is associated with low level of physical activity: A population-based study. Aliment Pharmacol Ther 2012;36:772-81.

29. Bae JC, Suh S, Park SE, et al. Regular exercise is associated with a reduction in the risk of NAFLD and decreased liver enzymes in individuals with NAFLD independent of obesity in Korean adults. PLoS One 2012;7:e46819.

30. Hallsworth K, Fattakhova G, Hollingsworth KG, et al. Resistance exercise reduces liver fat and its mediators in non-alcoholic fatty liver disease independent of weight loss. Gut 2011;60:1278-83.

31. Bhat G, Baba CS, Pandey A, Kumari N, Choudhuri G. Life style modification improves insulin resistance and liver histology in patients with non-alcoholic fatty liver disease. World J Hepatol 2012;4:209-17.

32. de Piano A, de Mello MT, Sanches Pde L, et al. Long-term effects of aerobic plus resistance training on the adipokines and neuropeptides in nonalcoholic fatty liver disease obese adolescents. Eur J Gastroenterol Hepatol 2012;24:1313-24.

33. Fealy CE, Haus JM, Solomon TP, et al. Short-term exercise reduces markers of hepatocyte apoptosis in nonalcoholic fatty liver disease. J Appl Physiol (1985) 2012;113:1-6.

34. Grønbæk H, Lange A, Birkebæk NH, et al. Effect of a 10-week weight loss camp on fatty liver disease and insulin sensitivity in obese Danish children. J Pediatr Gastroenterol Nutr 2012;54:223-8.
35. Sullivan S, Kirk EP, Mittendorfer B, Patterson BW, Klein S. Randomized trial of exercise effect on intrahepatic triglyceride content and lipid kinetics in nonalcoholic fatty liver disease. Hepatology 2012;55:1738-45.

36. Al-Jiffri O, Al-Sharif FM, Abd El-Kader SM, Ashmawy EM. Weight reduction improves markers of hepatic function and insulin resistance in type-2 diabetic patients with non-alcoholic fatty liver. Afr Health Sci 2013;13:667-72.

37. Bacchi E, Negri C, Targher G, et al. Both resistance training and aerobic training reduce hepatic fat content in type 2 diabetic subjects withnonalcoholic fatty liver disease (the RAED2 Randomized Trial). Hepatology 2013;58:1287-95.

38. Haus JM, Solomon TP, Kelly KR, et al. Improved hepatic lipid composition following short-term exercise in nonalcoholic fatty liver disease. J Clin Endocrinol Metab 2013;98:E1181-8.

39. Khaoshbaten M, Gholami N, Sokhtehzari S, Monazami AH, Nejad MR. The effect of an aerobic exercise on serum level of liver enzymes and liver echogenicity in patients with non alcoholic fatty liver disease. Gastroenterol Hepatol Bed Bench 2013;6:S112-6.

40. Malin SK, Mulya A, Fealy CE, et al. Fetuin-A is linked to improved glucose tolerance after short-term exercise training in nonalcoholic fatty liver disease. J Appl Physiol (1985) 2013;115:988-94.

41. Oh S, Tanaka K, Warabi E, Shoda J. Exercise reduces inflammation and oxidative stress in obesity-related liver diseases. Med Sci Sports Exerc 2013;45:2214-22.

42. Oh S, Shida T, Yamagishi K, Tanaka K, So R, Tsujimoto T, Shoda J Moderate to vigorous physical activity volume is an important factor for managingnon-alcoholic fatty liver disease: A retrospective study. Hepatology 2015;61:1205-15.

43. Zelber-Sagi S, Buch A, Yeshua $H$, et al. Effect of resistance training on non-alcoholic fatty-liver disease: A randomized-clinical trial. World J Gastroenterol 2014;20:4382-92.

44. Johnson NA, Sachinwalla T, Walton DW, et al. Aerobic exercise training reduces hepatic and visceral lipids in obese individuals without weight loss. Hepatology 2009;50:1105-12.

45. Lee S, Bacha F, Hannon T, Kuk JL, Boesch C, Arslanian S. Effects of aerobic versus resistance exercise without caloric restriction on abdominal fat, intrahepatic lipid, and insulin sensitivity in obese adolescent boys: A randomized, controlled trial. Diabetes 2012;61:2787-95.

46. Keating SE, Hackett DA, George J, Johnson NA. Exercise and non-alcoholic fatty liver disease: A systematic review and metaanalysis. J Hepatol 2012;57:157-66.

47. DeVore S, Kohli R, Lake K, Nicholas L, Dietrich K, Balistreri WF Xanthakos SA. A multidisciplinary clinical program is effective in stabilizing BMI and reducing transaminase levels in pediatric patients with NAFLD. J Pediatr Gastroenterol Nutr 2013;57:119-23.

48. Scaglioni F, Marino M, Ciccia S, et al. Short-term multidisciplinary non-pharmacological intervention is effective in reducing liver fat content assessed non-invasively in patients with nonalcoholic fatty liver disease (NAFLD). Clin Res Hepatol Gastroenterol 2013;37:353-8

49. Wong VW, Chan RS, Wong GL, et al. Community-based lifestyle modification programme for non-alcoholic fatty liver disease: A randomized controlled trial. J Hepatol 2013;59:536-42.

50. Croci I, Byrne NM, Choquette S, et al. Whole-body substrate metabolism is associated with disease severity in patients with nonalcoholic fatty liver disease. Gut 2013;62:1625-33.

51. Jin YJ, Kim KM, Hwang S, et al. Exercise and diet modification in non-obese non-alcoholic fatty liver disease: Analysis of biopsies of living liver donors. J Gastroenterol Hepatol 2012;27:1341-7.

52. Kitajima Y, Hyogo H, Sumida Y, et al. Severity of non-alcoholic steatohepatitis is associated with substitution of adipose tissue in skeletal muscle. J Gastroenterol Hepatol 2013;28:1507-14

53. Kawaguchi T, Shiba N, Maeda T, et al. Hybrid training of voluntary and electrical muscle contractions reduces steatosis, insulin resistance, and IL-6 levels in patients with NAFLD: A pilot study. J Gastroenterol 2011;46:746-57.

54. Castéra L, Vilgrain V, Angulo P. Noninvasive evaluation of NAFLD. Nat Rev Gastroenterol Hepatol 2013;10:666-75.

55. Neuman MG, Cohen LB, Nanau RM. Biomarkers in non-alcoholic fatty liver disease. Can J Gastroenterol Hepatol 2014;28:607-14.

56. Kim D, Kim WR, Kim HJ, Therneau TM. Association between noninvasive fibrosis markers and mortality among adults with nonalcoholic fatty liver disease in the United States. Hepatology 2013;57:1357-65. 
57. Boyraz M, Cekmez F, Karaoglu A, Cinaz P, Durak M, Bideci A. Serum adiponectin, leptin, resistin and RBP4 levels in obese and metabolic syndrome children with nonalcoholic fatty liver disease. Biomark Med 2013;7:737-45.

58. Koot BG, van der Baan-Slootweg OH, Bohte AE, et al. Accuracy of prediction scores and novel biomarkers for predicting nonalcoholic fatty liver disease in obese children. Obesity (Silver Spring) 2013;21:583-90.

59. Pacifico L, Bezzi M, Lombardo CV, et al. Adipokines and C-reactive protein in relation to bone mineralization in pediatric nonalcoholic fatty liver disease. World J Gastroenterol 2013;19:4007-14.

60. Klein M, Iazzettii L, Speiser P, et al. Alanine transferase: An independent indicator of adiposity related comorbidity risk in youth. J Diabetes September 30, 2014. doi: 10.1111/1753-0407.12221 (Epub ahead of print).

61. Sanches PL, de Piano A, Campos RM, et al. Association of nonalcoholic fatty liver disease with cardiovascular risk factors in obese adolescents: The role of interdisciplinary therapy. J Clin Lipidol 2014;8:265-72.

62. Polyzos SA, Toulis KA, Goulis DG, Zavos C, Kountouras J. Serum total adiponectin in nonalcoholic fatty liver disease: A systematic review and meta-analysis. Metabolism 2011;60:313-26.

63. Caro JF, Sinha MK, Kolaczynski JW, Zhang PL, Considine RV. Leptin: The tale of an obesity gene. Diabetes 1996;45:1455-62.

64. Bechmann LP, Kocabayoglu P, Sowa JP, et al. Free fatty acids repress small heterodimer partner (SHP) activation and adiponectin counteracts bile acid-induced liver injury in superobese patients with nonalcoholic steatohepatitis. Hepatology 2013;57:1394-406.

65. Fitzpatrick E, Mitry RR, Quaglia A, Hussain MJ, DeBruyne R, Dhawan A. Serum levels of CK18 M30 and leptin are useful predictors of steatohepatitis and fibrosis in paediatric NAFLD. J Pediatr Gastroenterol Nutr 2010;51:500-6.

66. Mazure RA, Salgado G, Villarreal P, Cobo B, Valencia A, Culebras JM. Intragastric balloon and multidisciplinary team. Nutr Hosp 2009;24:282-7.

67. Yasawy MI, Al-Quorain AA, Hussameddin AM, Yasawy ZM, Al-Sulaiman RM. Obesity and gastric balloon. J Family Community Med 2014;21:196-9.

68. Mafort TT, Madeira E, Madeira M, et al. Six-month intragastric balloon treatment for obesity improves lung function, body composition, and metabolic syndrome. Obes Surg 2014;24:232-40.

69. Dogan UB, Gumurdulu Y, Akin MS, Yalaki S. Five percent weight lost in the first month of intragastric balloon treatment may be a predictor for long-term weight maintenance. Obes Surg 2013;23:892-6.

70. Lee YM, Low HC, Lim LG, et al. Intragastric balloon significantly improves nonalcoholic fatty liver disease activity score in obese patients with nonalcoholic steatohepatitis: A pilot study. Gastrointest Endosc 2012;76:756-60.

71. Tai CM, Lin HY, Yen YC, et al. Effectiveness of intragastric balloon treatment for obese patients: One-year follow-up after balloon removal. Obes Surg 2013;23:2068-74.

72. Folini L, Veronelli A, Benetti A, et al. Liver steatosis (LS) evaluated through chemical-shift magnetic resonance imaging liver enzymes in morbid obesity; effect of weight loss obtained with intragastric balloon gastric banding. Acta Diabetol 2014;51:361-8.

73. Nobili V, Corte CD, Liccardo D, et al. Obalon intragastric balloon in the treatment of paediatric obesity: A pilot study. November 14, 2014. doi: 10.1111/ijpo.268 (Epub ahead of print).

74. Genco A, Maselli R, Frangella F, et al. Effect of consecutive intragastric balloon $(\mathrm{BIB} \AA)$ plus diet versus single $\mathrm{BIB} \AA$ plus diet on eating disorders not otherwise specified (EDNOS) in obese patients. Obes Surg 2013;23:2075-9.

75. Fuller NR, Pearson S, Lau NS, et al. An intragastric balloon in the treatment of obese individuals with metabolic syndrome: A randomized controlled study. Obesity (Silver Spring) 2013;21:1561-70.

76. Konopko-Zubrzycka M, Baniukiewicz A, Wróblewski E, et al. The effect of intragastric balloon on plasma ghrelin, leptin, and adiponectin levels in patients with morbidobesity. J Clin Endocrinol Metab 2009;94:1644-9.

77. Nikolic M, Boban M, Ljubicic N, et al. Morbidly obese are ghrelin and leptin hyporesponders with lesser intragastricballoon treatment efficiency: Ghrelin and leptin changes in relation to obesity treatment. Obes Surg 2011;21:1597-604.
78. Sekino Y, Imajo K, Sakai E, et al. Time-course of changes of visceral fat area, liver volume and liver fat area duringintragastric balloon therapy in Japanese super-obese patients. Intern Med 2011;50:2449-55.

79. Mion F, Napoléon B, Roman S, et al. Effects of intragastric balloon on gastric emptying and plasma ghrelin levels in non-morbid obese patients. Obes Surg 2005;15:510-6.

80. Bužga M, Evžen M, Pavel K, et al. Effects of the intragastric balloon MedSil on weight loss, fat tissue, lipid metabolism, and hormones involved in energy balance. Obes Surg 2014;24:909-15.

81. Geliebter A, Yahav EK, Gluck ME, Hashim SA. Gastric capacity, test meal intake, and appetitive hormones in binge eating disorder. Physiol Behav 2004;81:735-40.

82. Mathus-Vliegen EM, Eichenberger RI. Fasting and meal-suppressed ghrelin levels before and after intragastric balloons and ballooninduced weight loss. Obes Surg 2014;24:85-94.

83. Martinez-Brocca MA, Belda O, Parejo J, et al. Intragastric ballooninduced satiety is not mediated by modification in fasting or postprandial plasma ghrelin levels in morbid obesity. Obes Surg 2007;17:649-57.

84. Lassailly G, Caïazzo R, Pattou F, Mathurin P. Bariatric surgery for curing NASH in the morbidly obese? J Hepatol 2013;58:1249-51.

85. Sasaki A, Nitta H, Otsuka K, et al. Bariatric surgery and nonalcoholic fatty liver disease: Current and potential future treatments. Front Endocrinol (Lausanne) 2014;5:164

86. Taitano AA, Markow M, Finan JE, Wheeler DE, Gonzalvo JP, Murr MM. Bariatric surgery improves histological features of nonalcoholic fatty liver disease and liver fibrosis. J Gastrointest Surg 2015;19:429-36.

87. Andrade-Silva SG, Caranti DA, Sallet JA, Leal LP, Leal AJ, Dâmaso AR. Age and gender may influence the results of Roux-en-Y gastric bypass? Metabolic syndrome parameters. Arq Gastroenterol 2014;51:171-9.

88. Vargas V, Allende H, Lecube A, et al. Surgically induced weight loss by gastric bypass improves non alcoholic fatty liver disease in morbid obese patients. World J Hepatol 2012;4:382-8.

89. Cazzo E, Jimenez LS, Pareja JC, Chaim EA. Effect of Roux-en-y gastric bypass on nonalcoholic fatty liver disease evaluated through NAFLD fibrosis score: A prospective study. Obes Surg November 8, 2014 (Epub ahead of print).

90. Carazo A, León J, Casado J, et al. Hepatic expression of adiponectin receptors increases with non-alcoholic fatty liver disease progression in morbid obesity in correlation with glutathione peroxidase 1 . Obes Surg 2011;21:492-500.

91. Tai CM, Huang CK, Hwang JC, et al. Improvement of nonalcoholic fatty liver disease after bariatric surgery in morbidly obese Chinese patients. Obes Surg 2012;22:1016-21.

92. Felipo V, Urios A, García-Torres ML, et al. Alterations in adipocytokines and cGMP homeostasis in morbid obesity patients reverse after bariatric surgery. Obesity (Silver Spring) 2013;21:229-37.

93. Moschen AR, Molnar C, Wolf AM, et al. Effects of weight loss induced by bariatric surgery on hepatic adipocytokine expression. J Hepatol 2009;51:765-77.

94. Hosseinzadeh-Attar MJ, Golpaie A, Janani L, Derakhshanian H. Effect of weight reduction following bariatric surgery on serum visfatin and adiponectin levels in morbidly obese subjects. Obes Facts 2013;6:193-202.

95. Machado MV, Coutinho J, Carepa F, Costa A, Proença H, Cortez-Pinto H. How adiponectin, leptin, and ghrelin orchestrate together and correlate with the severity of nonalcoholic fatty liver disease. Eur J Gastroenterol Hepatol 2012;24:1166-72.

96. Vilarrasa N, Vendrell J, Sánchez-Santos R, et al. Effect of weight loss induced by gastric bypass on proinflammatory interleukin-18, soluble tumour necrosis factor-alpha receptors, C-reactive protein and adiponectin in morbidly obese patients. Clin Endocrinol (Oxf) 2007;67:679-86.

97. Illán-Gómez F, Gonzálvez-Ortega M, Orea-Soler I, et al. Obesity and inflammation: Change in adiponectin, C-reactive protein, tumour necrosis factor-alpha and interleukin- 6 after bariatric surgery. Obes Surg 2012;22:950-5.

98. Caiazzo R, Lassailly G, Leteurtre E, et al. Roux-en-Y gastric bypass versus adjustable gastric banding to reduce nonalcoholic fatty liver disease: A 5-year controlled longitudinal study. Ann Surg 2014:260:893-8.

99. Burza MA, Romeo S, Kotronen A, et al. Long-term effect of bariatric surgery on liver enzymes in the Swedish Obese Subjects (SOS) study. PLoS One 2013;8:e60495. 
100. Umemura A, Sasaki A, Nitta H, Otsuka K, Suto T, Wakabayashi G. Effects of changes in adipocyte hormones and visceral adipose tissue and the reduction of obesity-related comorbidities after laparoscopic sleeve gastrectomy in Japanese patients with severe obesity. Endocr J 2014;61:381-91.

101. Nazal L, Riquelme A, Solís N, et al. Hypoadiponectinemia and its association with liver fibrosis in morbidly obese patients. Obes Surg 2010;20:1400-7.

102. Kahraman A, Sowa JP, Schlattjan M, et al. Fetuin-A mRNA expression is elevated in NASH compared with NAFL patients. Clin Sci (Lond) 2013;125:391-400.

103. Pirvulescu I, Gheorghe L, Csiki I, et al. Noninvasive clinical model for the diagnosis of nonalcoholic steatohepatitis in overweight and morbidly obese patients undergoing bariatric surgery. Chirurgia (Bucur) 2012;107:772-9.

104. Estep M, Abawi M, Jarrar M, et al. Association of obestatin, ghrelin, and inflammatory cytokines in obese patients with non-alcoholic fatty liver disease. Obes Surg 2011;21:1750-7.

105. Bužga M, Zavadilová V, Holéczy $\mathrm{P}$, et al. Dietary intake and ghrelin and leptin changes after sleeve gastrectomy. Wideochir Inne Tech Malo Inwazyjne 2014;9:554-61.

106. Moschen AR, Molnar C, Geiger S, et al. Anti-inflammatory effects of excessive weight loss: Potent suppression of adipose interleukin 6 and tumour necrosis factor alpha expression. Gut 2010;59:1259-64.

107. Bray GA, Popkin BM. Calorie-sweetened beverages and fructose: What have we learned 10 years later. Pediatr Obes 2013;8:242-8.

108. Lê KA, Ith M, Kreis R, et al. Fructose overconsumption causes dyslipidemia and ectopic lipid deposition in healthy subjects with and without a family history of type 2 diabetes. Am J Clin Nutr 2009;89:1760-5.

109. Jin R, Willment A, Patel SS, et al. Fructose induced endotoxemia in pediatric nonalcoholic fatty liver disease. Int J Hepatol 2014;2014:560620.

110. Kanerva N, Sandboge S, Kaartinen NE, Männistö S, Eriksson JG. Higher fructose intake is inversely associated with risk of nonalcoholic fatty liver disease in older Finnish adults. Am J Clin Nutr 2014;100:1133-8.

111. Yang M, Gong S, Ye SQ, et al. Non-alcoholic fatty liver disease in children: Focus on nutritional interventions. Nutrients 2014;6:4691-705

112. Volynets V, Machann J, Küper MA, et al. A moderate weight reduction through dietary intervention decreases hepatic fat content in patients with non-alcoholic fatty liver disease (NAFLD): A pilot study. Eur J Nutr 2013;52:527-35.
113. Johnston RD, Stephenson MC, Crossland H, et al. No difference between high-fructose and high-glucose diets on liver triacylglycerol or biochemistry in healthy overweight men. Gastroenterology 2013;145:1016-25.

114. Chung M, Ma J, Patel K, Berger S, Lau J, Lichtenstein AH. Fructose, high-fructose corn syrup, sucrose, and nonalcoholic fatty liver disease or indexes of liver health: A systematic review and meta-analysis. Am J Clin Nutr 2014;100:833-49.

115. Chiu S, Sievenpiper JL, de Souza RJ, et al. Effect of fructose on markers of non-alcoholic fatty liver disease (NAFLD): A systematic review and meta-analysis of controlled feeding trials. Eur J Clin Nutr 2014;68:416-23.

116. Carvalhana S, Machado MV, Cortez-Pinto H. Improving dietary patterns in patients with nonalcoholic fatty liver disease. Curr Opin Clin Nutr Metab Care 2012;15:468-73.

117. O'Sullivan TA, Oddy WH, Bremner AP, et al. Lower fructose intake may help protect against development of nonalcoholic fatty liver in adolescents with obesity. J Pediatr Gastroenterol Nutr 2014;58:624-31.

118. Mager DR, Iñiguez IR, Gilmour S, Yap J. The Effect of a Low Fructose and Low Glycemic Index/Load (FRAGILE) dietary intervention on indices of liver function, cardiometabolic risk factors, and body composition in children and adolescents with nonalcoholic fatty liver disease (NAFLD). JPEN J Parenter Enteral Nutr 2015;39:73-84.

119. Sullivan JS, Le MT, Pan Z, et al. Oral fructose absorption in obese children with non-alcoholic fatty liver disease. Pediatr Obes June 24, 2014. doi: 10.1111/ijpo.238 (Epub ahead of print).

120. Jin R, Le NA, Liu S, et al. Children with NAFLD are more sensitive to the adverse metabolic effects of fructose beverages than children without NAFLD. J Clin Endocrinol Metab 2012;97:E1088-98.

121. Abdelmalek MF, Lazo M, Horska A, et al. Higher dietary fructose is associated with impaired hepatic adenosine triphosphate homeostasis in obese individuals with type 2 diabetes. Hepatology 2012;56:952-60.

122. Nomura K, Yamanouchi T. The role of fructose-enriched diets in mechanisms of nonalcoholic fatty liver disease. J Nutr Biochem 2012;23:203-8.

123. Chalasani N, Younossi Z, Lavine JE et al. The diagnosis and management of non-alcoholic fatty liver disease: Practice guideline by the American Association for the Study of Liver Diseases, American College of Gastroenterology, and the American Gastroenterological Association. Hepatology 2012;55:2005-23. 


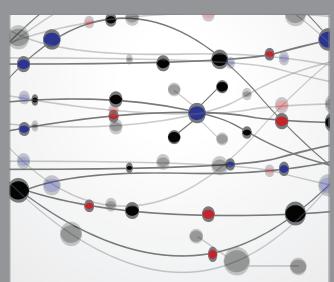

The Scientific World Journal
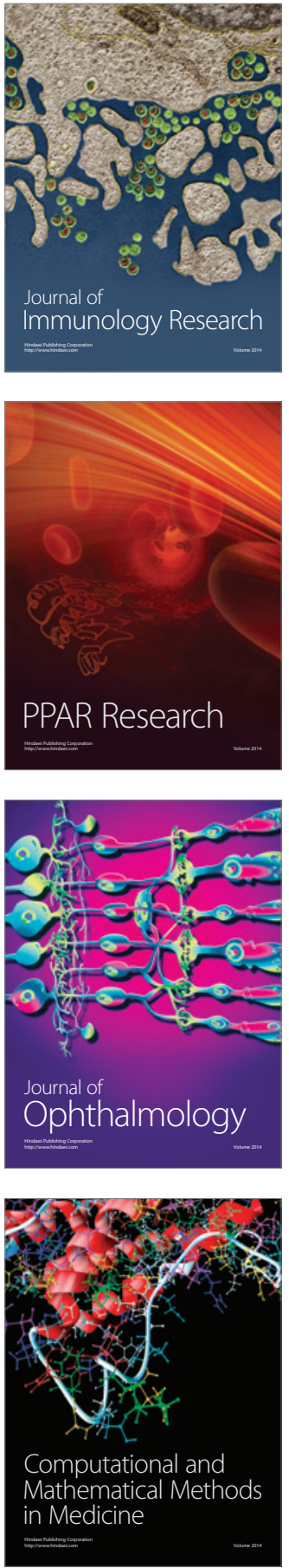

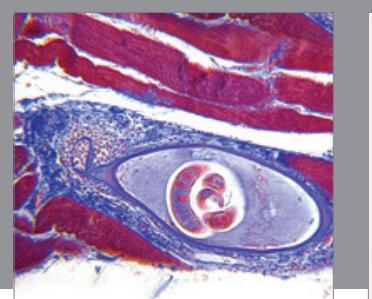

Gastroenterology Research and Practice

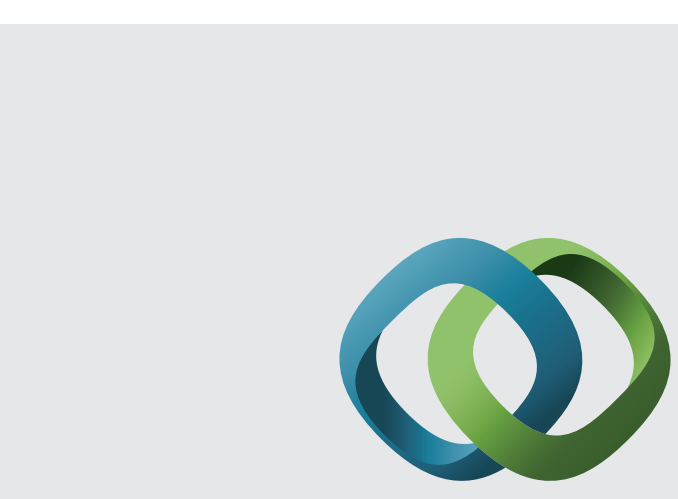

\section{Hindawi}

Submit your manuscripts at

http://www.hindawi.com
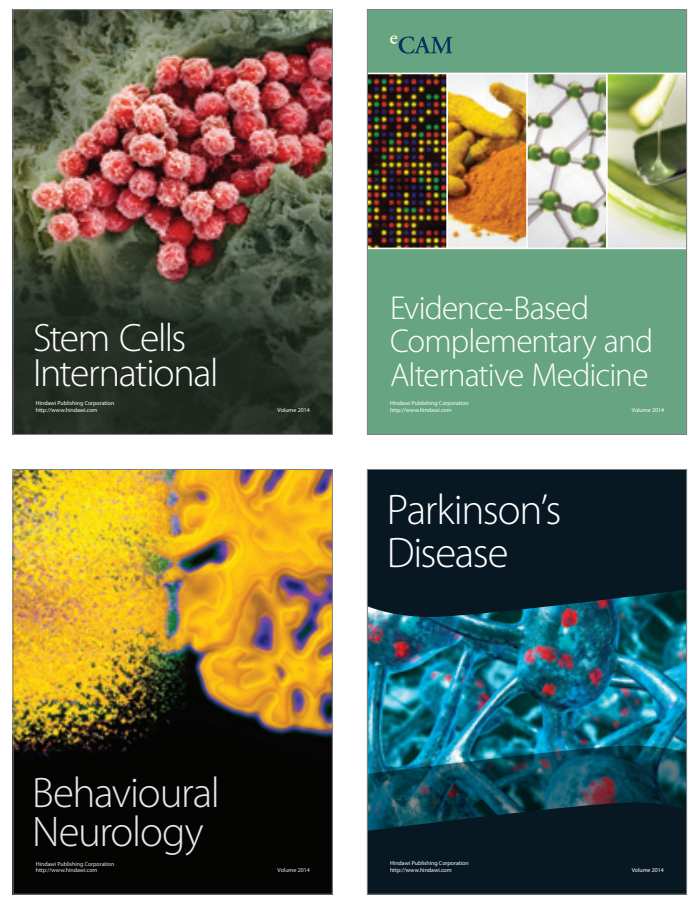
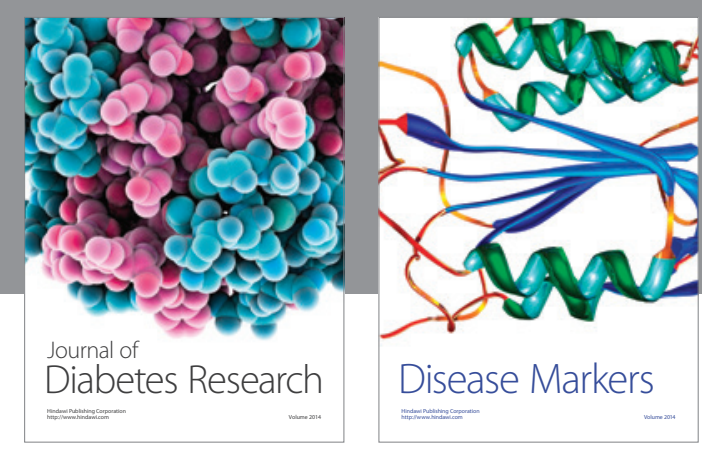

Disease Markers
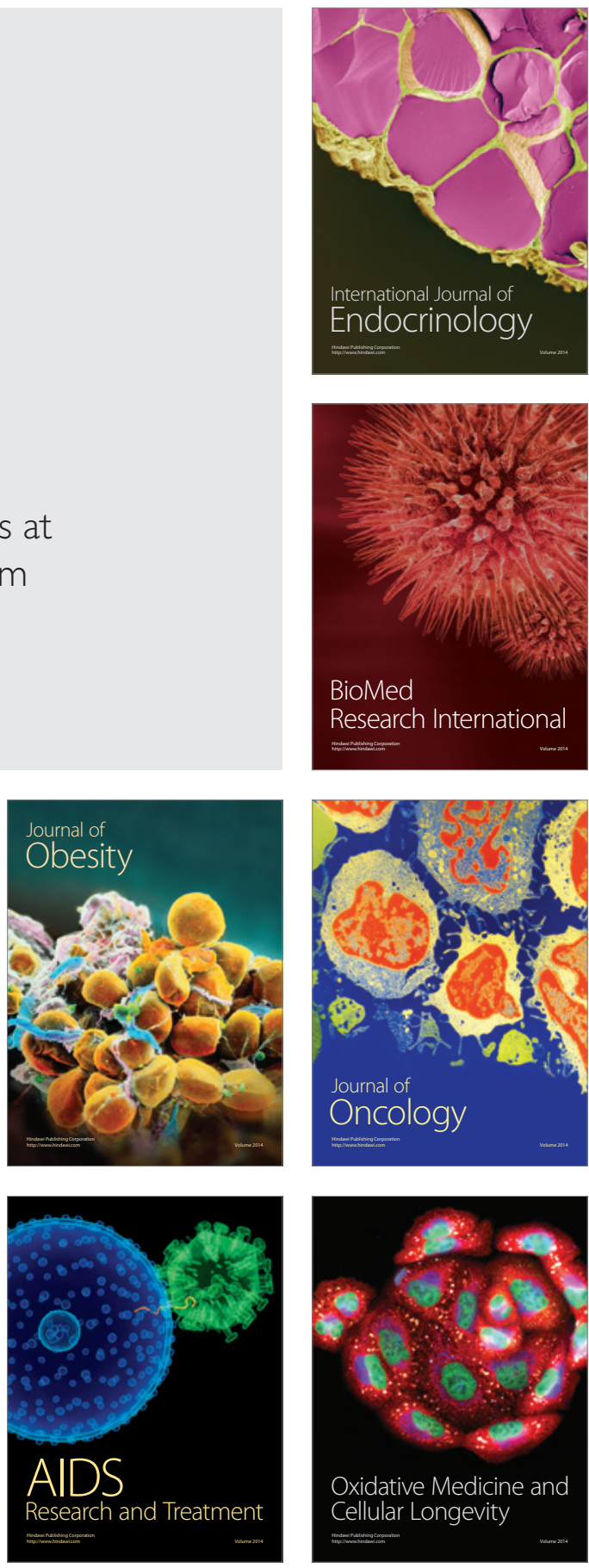